UNIVERSIDADE DE SÃO PAULO

ESCOLA DE ENFERMAGEM DE RIBEIRÃO PRETO

LIS APARECIDA DE SOVZA JNEVES

Prevenção da transmissão vertical do HIV/aids: compreendendo as crenças e percepções das mães soropositivas. 


\section{Prevenção da transmissão vertical do HIV/aids: compreendendo as crenças e percepções das mães soropositivas.}

Dissertação apresentada à Escola de Enfermagem de Ribeirão Preto da Universidade de São Paulo para obtenção do título de Mestre em Enfermagem Fundamental junto ao Departamento de Enfermagem Geral e Especializada, inserido na linha de pesquisa: Doenças Infecciosas - problemáticas e estratégias de enfrentamento.

Orientadora: Profa. Dra. Elucir Gir 
AUTORIZO A DIVULGAÇÃO TOTAL OU PARCIAL DESTE TRABALHO, POR QUALQUER MEIO CONVENCIONAL OU ELETRÔNICO, PARA FINS DE ESTUDO E PESQUISA, DESDE QUE CITADA A FONTE.

FICHA CATALOGRÁFICA

Neves, Lis Aparecida de Souza.

Prevenção da transmissão vertical do HIV/aids: compreendendo as crenças e percepções das mães soropositivas. Ribeirão Preto, 2005.

$114 \mathrm{p}$.

Dissertação de Mestrado apresentada à Escola de Enfermagem de Ribeirão Preto/USP. Área de concentação: Doenças Infecciosas.

Orientadora: Gir, Elucir.

1. HIV. 2. aids. 3. transmissão vertical de doença. 4. mulher. 5. prevenção. 
Prevenção da transmissão vertical do HIV/aids: compreendendo as crenças e percepções das mães soropositivas.

\begin{abstract}
Dissertação apresentada à Escola de Enfermagem de Ribeirão Preto da Universidade de São Paulo para obtenção do título de Mestre em Enfermagem Fundamental junto ao Departamento de Enfermagem Geral e Especializada, inserido na linha de pesquisa: Doenças Infecciosas - problemáticas e estratégias de enfrentamento.
\end{abstract}

Data da defesa:

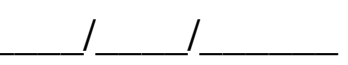

Banca examinadora:

Profa. Dr ${ }^{\mathrm{a}}$. Elucir Gir

Instituição:

Assinatura:

Profa. Dra ${ }^{a}$. Renata Ferreira Takahashi

Instituição:

Assinatura:

Profa $^{a}$. Dra . Ana Maria de Almeida

Instituição:

Assinatura: 
Dedicatória

Ao Matias, meu eterno namorado e melhor amigo, pelo convívio intenso e verdadeiro, pelo amor, carinho e dedicação. Obrigado por compartilhar comigo sua vida, nossos sonhos e nossas conquistas.

À Taís e Mateus, que sempre estiveram ao meu lado, suportando as minhas ausências e me apoiando com amor e compreensão, me ensinando que além de filhos, são meus companheiros em todos os momentos.

Ama-os profundamente e dedica-lhes este trabalba. 


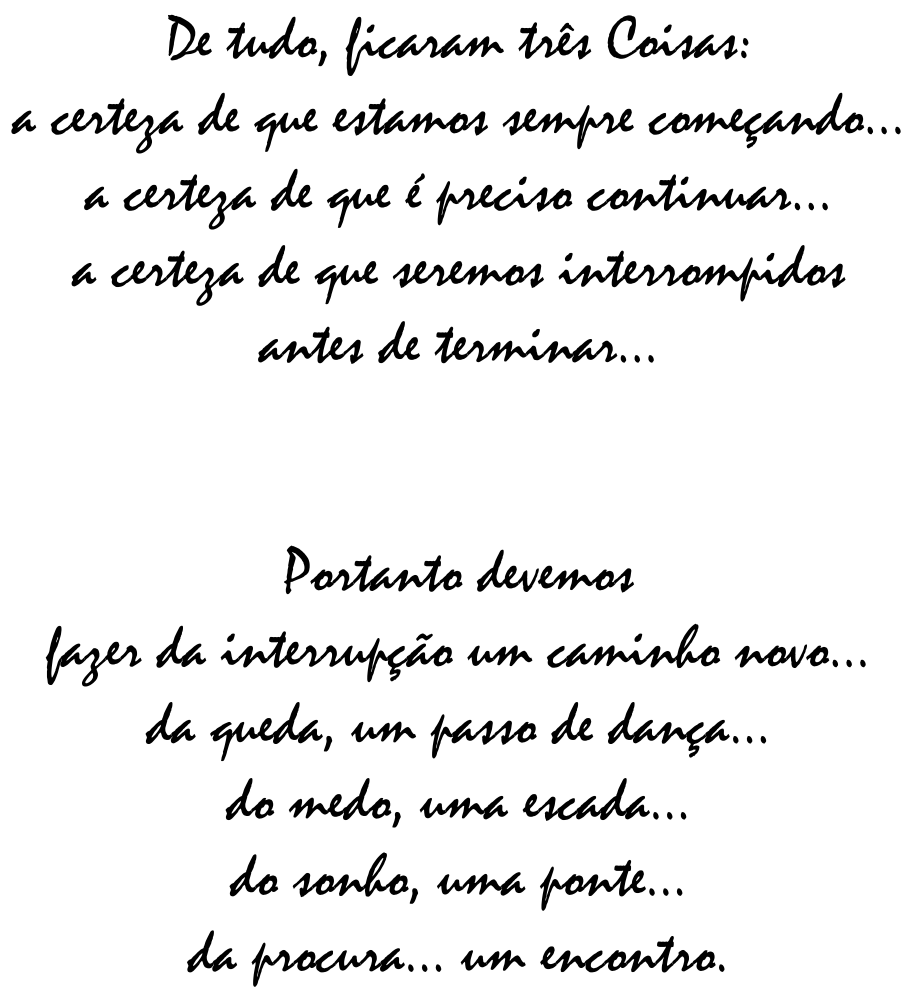

De tuda, ficaram três Caisas: a certeza de que estamos sempre começanda... a cesteza de que é precisa continuar... a certeza de que seremas intersampidas antes de terminar...

\section{Portanta devemas}

lazer da intersupção um caminho nova... da queda, um passo de dança... do medo, uma escada... do somba, uma pante... da procura... um encontra.

\section{FERNANTO PESSOA}

Leandro Eduardo, Du, meu irmão querido, confidente nas horas de alegria e dor, que tanto me incentivou a entrar na Pós-graduação; foi o meu exemplo de força, luta e determinação na vida. Hoje você vive na luz da eternidade, mas eu tenho certeza que está muito feliz e vibrando com essa conquista. 


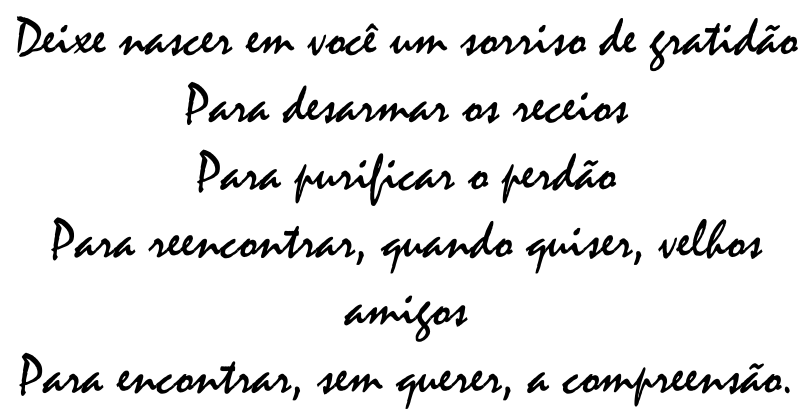

THAIS REGINA ISMAIL

\section{Agradecimentos}

A Deus, por permitir o convívio com as pessoas que amo e sempre nos dar forças para continuar.

Agradecer nominalmente a todas as pessoas que de uma forma ou de outra, me auxiliaram durante este processo, torna-se tarefa quase impossível. A todos, minha gratidão.

Agradecimentos especiais:

Profa. Elucir Gir, por ter aceitado o desafio dessa orientação e acreditando em mim, pela paciência com minhas dificuldades de iniciante na pesquisa científica, obrigada pelo constante apoio, o compartilhar de idéias e a competência com que me conduziu nesta trajetória.

Profa. Ana Maria de Almeida, a quem agradeço a oportunidade de aprendizado obtida a cada contato que tivemos.

Profa. Renata Takahashi, pelas sugestões que contribuíram para o aperfeiçoamento deste trabalho.

A todos os docentes das disciplinas que freqüentei, por terem feito parte dessa caminhada.

Aos funcionários da EERP-USP, em especial do Departamento de Enfermagem Geral e Especializada, da Pós-Graduação, da sala de leitura e da sala Pró-aluno, pelo apoio e auxílio em todos os momentos.

A minha mãe, meu exemplo de vida e superação, pelo amor incondicional e infinito, por me encher de coragem e ensinar a não ter medo na vida.

João, pela paciência, pela mão estendida em todas as horas, pelo carinho e atenção com que sempre cuidou de minha mãe e de toda minha família.

Ao meu pai, pela confiança que depositou em mim a vida inteira.

Aos meus sogros Joaquim e Ranulfa, por me acolherem em uma família que sabe amar e se doar ao outro, e que está sempre presente seja para aplaudir ou para amortecer a queda.

À Fernanda e aos meus afilhados Ronan e Darriê, guerreiros na vida, pelas palavras carinhosas nos momentos difíceis, e pela confiança que sempre tiveram em mim. 
Thaís e Renato, amigos e agora "compadres", com quem partilhamos tantos momentos de dificuldades e alegrias. Vocês nos deram dois presentes que iluminam e trazem alegria às nossas vidas: o Thales e o Thárik.

Regininha e Cri (Luis Henrique), pela convivência, pela amizade, companheirismo e apoio constante. Vocês são pessoas iluminadas, que tenho a felicidade de poder chamar de amigos.

Cláudia e Cássia, amigas desde sempre, presentes em tantos momentos de minha vida e que eu sei que posso contar a qualquer hora.

À Márcia Cristina e Maria Renata, amigas que me "acolhem" diariamente, que se desdobraram no trabalho permitindo minhas ausências na busca da qualificação. Tenho muito a agradecer vocês pela confiança, pela preocupação, pelo companheirismo do dia a dia, pelo apoio e incentivo o tempo todo.

Luciana e Vanda, obrigado pela amizade, pela alegria e bom humor que fazem a diferença, e principalmente, pela palavra amiga presente no momento mais difícil...

Rita e Miguel, companheiros em outros momentos de trabalho e que as idas e vindas da vida nos colocaram juntos novamente, agora também na companhia da Aracele, da Márcia, Dr. Harnoldo, Dr. Nilton. É um prazer trabalhar com quem ama o que faz e trata a todos com atenção, respeito e carinho. Minha sincera admiração por todos vocês.

Á toda equipe do Programa Municipal de DST/aids, especialmente à Fátima, Marisa, Marta e Stella, por permitirem que eu também me apaixonasse pelas questões tão complexas que envolvem a temática da aids.

Aos colegas da Secretaria Municipal da Saúde de Ribeirão Preto: Marta Angélica, Marina, Nélio, Eliana, Janise, Denise, Alberto e todos os que convivem diariamente com as incertezas, angústias e sonhos de uma saúde pública com qualidade e equidade.

À Adriana Mafra e Rosana, pela força e estímulo para que eu criasse coragem de fazer a pósgraduação.

Aos amigos que estiveram de alguma forma presentes durante a realização deste trabalho.

E, especialmente,

Ás mães soropositivas, que me permitiram entrar em suas casas e partilhar uma parte singular de suas histórias, meu muito obrigado. 
"Creic que podemos transformas a tragédia da AIDS, da enfermidade e da doenca, num desafica, numa opostumidade, numa passibilidade de secupesas na nossa sociedade, en nós mesmos, em cada um de nós e em todas nós, o sentido da vida e da dignidade. E, com esse sentido da vida e da dignidade, sesemas capazes de lutas pela construçãa de uma saciedade demacrática; de uma sociedade justa e fraterna".

Herbert de Sayza, Betinka 
NEVES, L. A. S. Prevenção da transmissão vertical do HIVlaids: compreendendo as crenças e percepções das mães soropositivas. Dissertação (mestrado). Escola de Enfermagem de Ribeirão Preto da Universidade de São Paulo. Ribeirão Preto, 2005.

\section{RESUMO}

As medidas preventivas da transmissão vertical do HIV podem efetivamente reduzir as taxas da infecção nas crianças. No entanto, são necessárias a participação e adesão das mães ao tratamento. Buscando compreender as crenças que influenciam o comportamento das mães portadoras do HIV em relação às medidas profiláticas da transmissão vertical, desenvolvemos este estudo qualitativo. Foram entrevistadas 14 mulheres portadoras do HIV cujos filhos nasceram no município de Ribeirão Preto e tinham no mínimo 6 meses de vida. Os dados foram tratados de acordo com o método da Análise de Conteúdo e interpretados utilizandose como referencial teórico o Modelo de Crenças em Saúde (Rosenstock, 1974), composto pelas dimensões susceptibilidade percebida, severidade percebida, benefícios percebidos e barreiras percebidas. Na análise emanaram categorias que evidenciam as contradições da epidemia da aids: na susceptibilidade percebida emergiram "invulnerabilidade antes da gravidez", "o pré-natal" e "susceptibilidade da criança"; quanto à severidade da doença - "subestimação do HIV" e "medo da morte"; "crescer saudável" e "não ser como eu", foram os benefícios percebidos pelas mães; em relação às barreiras possíveis, encontramos a "descrença na existência do vírus", "dificuldades financeiras" e "omissão do diagnóstico". Alguns aspectos das crenças podem ser considerados tanto como facilitadores como dificultadores da adesão materna, dependendo do contexto sócio-econômico e cultural em que vive a mãe. Conhecer a percepção das mães acerca das crenças que motivam os seus comportamentos proporciona aos profissionais de saúde maior compreensão desses comportamentos, permitindo ainda a possibilidade de elaboração de um planejamento mais efetivo de cuidados dentro de um contexto culturalmente significativo, com maior probabilidade de promover a adesão da clientela.

Descritores: HIV, aids, transmissão vertical de doença, mulher, prevenção. 
NEVES, L. A. S. Prevention for mother-to-child transmission: understanding HIV positive mother's beliefs and perceptions. Masters Dissertation. University of São Paulo at Ribeirão Preto College of Nursing. Ribeirão Preto, 2005.

\section{SUMMARY}

Prevention measures for the mother-to-child transmission of the HIV virus may effectively reduce infection rates in children. However, for such effectiveness to come true, mothers have to comply with the treatment. This study was carried out aiming to understand the beliefs which influence the HIV positive mothers' behaviors towards prevention methods against mother-to-child transmission. Fourteen HIV infected women whose children were at least 6 months old and all born in Ribeirão Preto county were interviewed. Data were studied according to the Content Analyses method and interpreted using as a theoretical reference the Health Belief Model (Rosenstock, 1974), formed by the following dimensions: perceived susceptibility, perceived severity, perceived benefits and perceived obstacles. As we analyzed those data we came up with some under categories showing the AIDS epidemic paradox: in the perceived susceptibility appeared: "invulnerability prior to pregnancy"; "pre delivery"; "a child's susceptibility" as for the disease seriousness. "Underestimation of the HIV virus";" fear of death"; "healthy growing up"; and "not the same as me" were the benefits mentioned by the mothers. As for the possible barriers, we found things like: "disbelief in the virus existence"; "financial problems"; "diagnosis omission". Some aspects of the beliefs may be considered both helpers and trouble-makers for a mother's adhesion, varying according to the social, economic and cultural environment the mother lives in. Getting to know a mother's perception regarding the beliefs motivating their behaviors provides the health professionals a higher understanding of such behaviors, allowing the possibility of making up an effective care plan within the context culturally meaningful, with a higher probability of promoting patients' adhesion.

Describers: HIV, Aids, mother-to-child disease transmission, women, prevention. 
NEVES, L. A. S. Prevención de la transmisión vertical del VIH/sida: comprendiendo las creencias y percepciones de las madres seropositivas. Disertación (maestría). Escuela de Enfermería de Ribeirão Preto, Universidad de São Paulo. Ribeirão Preto, 2005.

\section{RESUMEN}

Las medidas para la prevención de la transmisión vertical del HIV son capaces de realmente reducir las tasas de infección en niños. Sin embargo, las madres deben participar de y adherir al tratamiento. El objetivo de este estudio cualitativo fue comprender las creencias que influencian el comportamiento de las madres HIV respecto a las medidas profilácticas de la transmisión vertical. Fueron entrevistadas 14 mujeres portadoras de HIV cuyos hijos, con un mínimo de 6 meses de edad, nacieron en Ribeirao Preto. Los datos fueron tratados según el método de Análisis de Contenido, utilizando como referencial teórico el Modelo de Creencias de la Salud (Rosenstock, 1974), que es compuesto por las dimensiones de susceptibilidad percibida, severidad percibida, beneficios percibidos y barreras percibidas. Del análisis surgieron categorías que evidencian las contradicciones de la epidemia de SIDA: de la susceptibilidad emergieron "invulnerabilidad antes del embarazo", "el prenatal" y "susceptibilidad del niño"; respecto a la severidad de la enfermedad - "subestimación del HIV" y "miedo de la muerte"; las madres percibieron "crecer saludable" y "no ser como yo" como beneficios; con relación a las barreras posibles, encontramos "no creer en la existencia del virus", "dificultades financieras" y "omisión del diagnóstico". Algunos aspectos de las creencias pueden ser considerados no sólo como facilitadores, pero también como dificultadores de la adherencia materna, dependiendo del contexto socioeconómico y cultural de la madre. Conocer la percepción de las madres acerca de las creencias que motivan sus comportamientos proporciona a los profesionales de salud mayor comprensión de esos comportamientos y también les permite elaborar un planeo más efectivo de cuidados dentro de un contexto culturalmente significativo, con mayor probabilidad de promover la adherencia de la clientela.

Descriptores: VIH, sida, transmisión vertical de enfermedad, mujer, prevención. 


\section{Lista de siglas e abreviaturas}

ACS - agente comunitário de saúde

ACTG - Aids Clinical Trials Group

AICA - Ambulatório de Infectologia em Crianças e Adolescentes

AMIB - Ambulatório de Moléstias Infecciosas em Berçário

AMIGO - Ambulatório de Moléstias Infecciosas em Ginecologia e Obstetrícia

ARVs - Medicamentos anti-retrovirais

AZT - Zidovudina

CDC - Center for Disease Control and Prevention

CNDSTIAids - Coordenação Nacional de Doenças Sexualmente Transmissíveis e Aids

HCFMRP-USP - Hospital das Clínicas da Faculdade de Medicina de Ribeirão Preto da Universidade de São Paulo

HIV - vírus da imunodeficiência humana

IST - Infecção sexualmente transmissível

MCS - Modelo de Crenças em Saúde

PSF - Programa de Saúde da Família

RN - Recém nascido

SMS - Secretaria Municipal da Saúde

SUS - Sistema Único de Saúde

UBS - Unidade Básica de Saúde

UDI - Usuário de drogas injetáveis

UNAIDS - Programa Conjunto das Nações Unidas sobre HIV/aids. 


\section{Sumário}

Resumo

Abstract

Resumen

Lista de siglas e abreviaturas

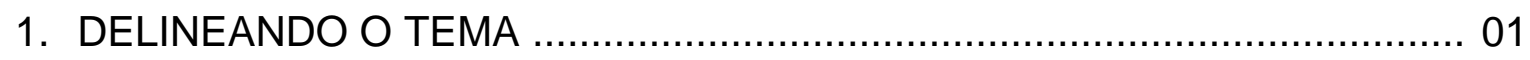

1.1. Trajetória e tendências da epidemia ....................................... 02

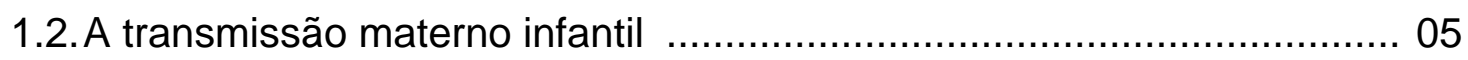

1.3. O município de Ribeirão Preto .............................................. 12

1.4. A adesão às medidas preventivas da transmissão materno infantil ........ 16

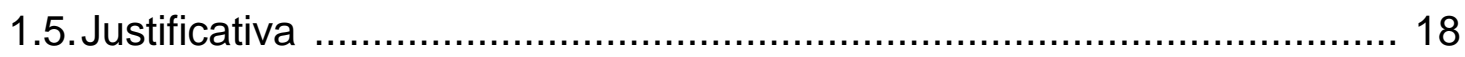

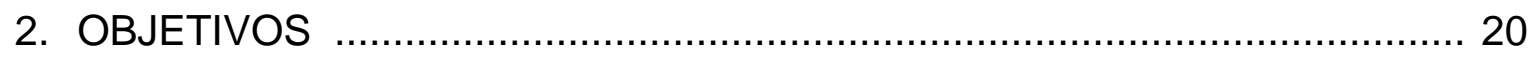

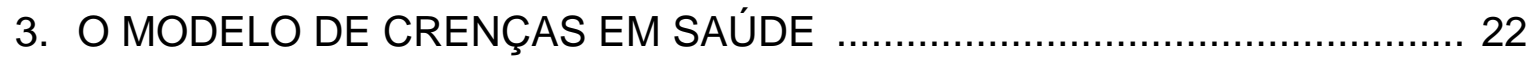

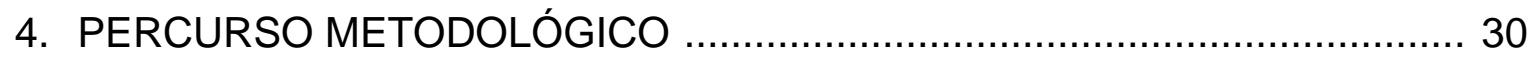

4.1. População e Amostra .......................................................... 31

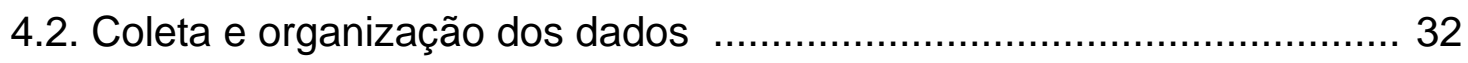

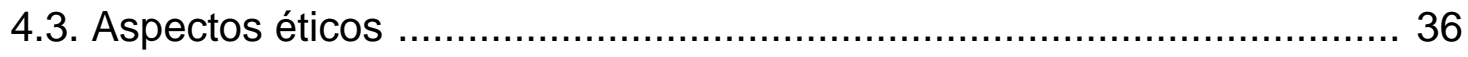

5. APRESENTANDO E DISCUTINDO OS RESULTADOS .......................... 37

5.1. Breve descrição das participantes ............................................ 38

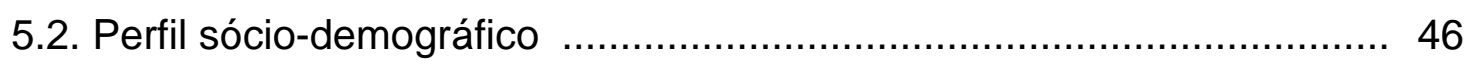

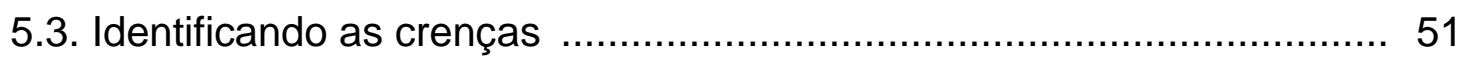

A - Percepção de Susceptibilidade....................................... 52

A.1. Invulnerabilidade antes da gravidez ........................... 53

A.2. O pré-natal........................................................ 59

A.3. Susceptibilidade da criança .................................... 64 


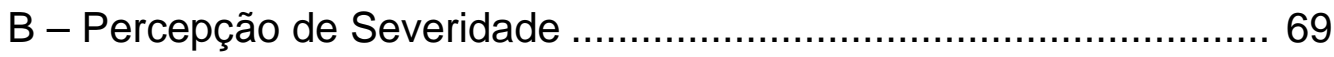

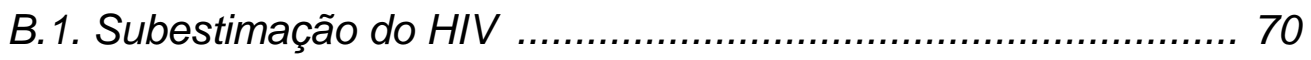

B.2. Medo da morte .................................................................. 76

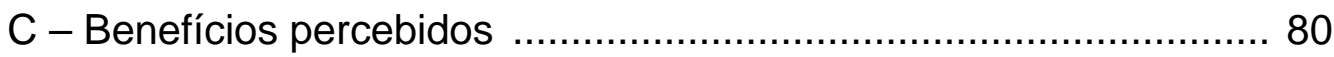

C.1. Crescer saudável .......................................................... 80

C.2. Não ser como eu ............................................................... 82

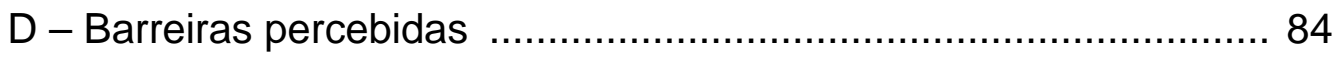

D.1. Descrença na existência do vírus .................................... 85

D.2. Dificuldades financeiras .................................................. 89

D.3. Omissão do diagnóstico ................................................. 93

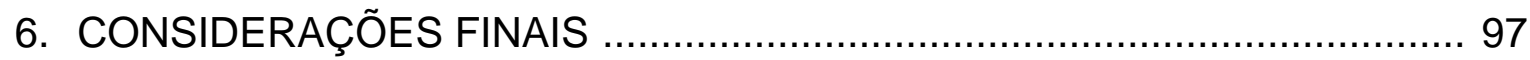

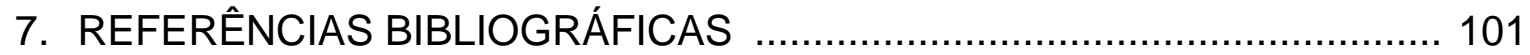

Anexos 


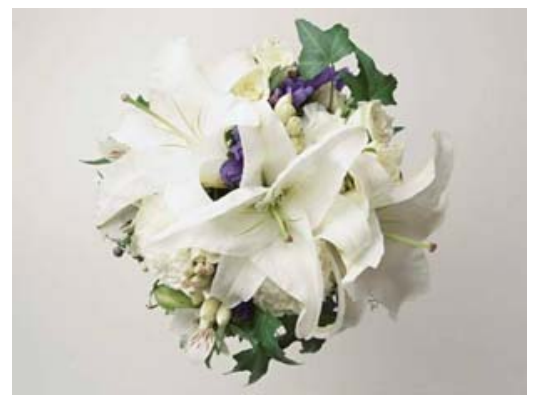

1. Delineando o tema 


\section{DELINEANDO O TEMA}

\subsection{TRAJETÓRIA E TENDÊNCIAS DA EPIDEMIA}

A Organização Mundial de Saúde estima que 40 milhões de pessoas estejam vivendo com o Vírus da Imunodeficiência Humana (HIV) no mundo todo, configurando a infecção como a mais importante epidemia contemporânea. Cerca de metade de todos os adultos infectados são mulheres e 2.500 .000 de crianças estão vivendo com o vírus, sendo que a situação é particularmente mais grave nos países da África sub-sahariana, onde vivem quase 85\% destas crianças. Em 2004, 640.000 novas crianças foram infectadas (WHO, 2004).

No Brasil, até junho de 2004 foram notificados 9122 casos confirmados de aids $^{1}$ entre indivíduos menores de 13 anos de idade (BRASIL, 2004a), sendo a transmissão vertical responsável por cerca de $83,6 \%$ destes casos.

O primeiro registro identificado da aids no Brasil ocorreu em 1980, notificado na cidade de São Paulo (BRASIL, 2004a), seguido de outros casos restritos às regiões metropolitanas até 1985. A partir daí, ocorreram casos que foram em outras regiões do país, e podemos dizer que estamos vivenciando, desde a segunda metade da década de 90, um claro processo de interiorização da epidemia (BRASIL, 2004a).

1. As siglas adotadas neste trabalho seguem o padrão recomendado pelo Ministério da Saúde: a palavra aids será considerada um substantivo comum quando se referir à epidemia, sendo grafada em caixa baixa. O uso em caixa alta e baixa ocorrerá quando se referir nome de um setor, título, por exemplo Coordenação Nacional de DST e Aids. 
Os estudos epidemiológicos iniciais buscavam ativamente fatores de risco associáveis à doença, dando origem ao conceito de "grupos de risco", expressão esta, que mesmo superada, marcou irreversivelmente a construção social e histórica da aids, implicando na discriminação, estigma, preconceito e exclusão do indivíduo infectado. É a recriminação do sujeito que transgrediu, que se comportou fora do recomendável.

Revendo a história da epidemia no Brasil, conforme ressaltado por Herbert de Souza, Betinho ${ }^{2}$, sociólogo infectado pelo HIV por transfusão de sangue e fundador da Associação Brasileira Interdisciplinar da Aids, "a Aids chegou antes da Aids", constituindo-se este fato em importante dimensão a ser compreendida para analisar a história social da doença. Galvão (2000), destaca a importância da mídia na forma como a aids chegou ao Brasil, associada aos homossexuais pertencentes à classe média, intelectuais e artistas. Em seguida, intensificou-se a transmissão sanguínea e o grupo dos usuários de drogas injetáveis se destacou no curso da epidemia.

"Ao contrário do que se pensou inicialmente, a infecção pelo HIV não se limita à identidade sexual, mas a comportamentos adotados" (GIR, 1997, p.28). A epidemia que iniciou entre indivíduos homossexuais masculinos, passou pelos hemotransfundidos, pelos usuários de drogas injetáveis e nos últimos anos, tem apresentado como principal categoria de exposição, a via sexual com destaque aos heterossexuais.

A via sexual é a forma predominante de transmissão no Brasil, principalmente entre a população feminina.

Os últimos dados apresentados pelo Ministério da Saúde nos mostra que a 
epidemia de aids no Brasil continua em patamares elevados, tendo atingido em 2003 a incidência de 18,4 casos por 100.000 habitantes. Nos homens há uma tendência de estabilização, sendo registrada uma taxa menor do que a de 1998. No entanto, o crescimento continua entre as mulheres, sendo que em 2003 ocorreu a maior taxa de incidência nesse grupo populacional: 14,1 casos por 100.000 mulheres. Outro dado que corrobora o aumento da epidemia entre as mulheres é a proporcionalidade entre o os sexos: em 1985 o número de casos correspondia à proporção de 28 indivíduos do sexo masculino para um do sexo feminino; desde 1998, esta relação diminuiu, sendo que para cada caso feminino tem sido registrado apenas 2 casos masculinos (BRASIL, 2004 a).

Segundo Santos et al (2002), a velocidade de crescimento da epidemia é maior entre as mulheres do que entre os homens. Para Gir et al (2004) a transmissão do homem para a mulher ocorre mais efetivamente, tanto devido às desvantagens biológicas (como por exemplo a maior extensão da mucosa vaginal), como pelo fato do vírus apresentar-se em quantidade muito maior no líquido seminal, quando comparado ao fluído vaginal.

O avanço do HIVIAIDS entre as mulheres é indicativo não apenas das dificuldades em oferecer respostas institucionais para a contenção da epidemia, mas também remete para as questões que envolvem a identidade de gênero que determinam os papéis sociais de homens e mulheres, cuja assimetria aumenta a vulnerabilidade das mulheres à infecção. Assim, a mulher é a grande vítima da transmissão heterossexual. Se considerarmos que $85 \%$ das mulheres infectadas pelo HIV estão em idade fértil, tem-se o problema adicional da transmissão vertical do HIV, também denominada materno infantil, que representa a principal forma de disseminação desse vírus na população infantil. 
As desigualdades de gênero associadas à mobilidade e ao subdesenvolvimento econômico foram os fatores estruturais facilitadores da disseminação do HIVlaids agrupados por Parker e Camargo Jr. (2000). Para estes autores, o processo de globalização e a série de transformações nas estruturas das sociedades são talvez os fatores relativos mais importantes a serem buscados no entendimento da evolução global da epidemia.

No entanto, se este conjunto de transformações tem proporcionado a conexão entre as elites ao redor do mundo, ao mesmo tempo surgem novas formas de exclusão social e extremos de desigualdade diferenciais de renda, pobreza e miséria. Estas transformações têm impactado desproporcionalmente a vida das mulheres, acentuando a feminização da pobreza e da miséria. Associado a essa tendência de feminização da pobreza tem-se a epidemia de HIV/aids cujas taxas de incidência nos últimos anos tem atingido principalmente as mulheres com menor escolaridade (FONSECA et al, 2000).

Feminização, pobreza, baixa escolaridade, exclusão social são fatores que, além de proporcionar uma velocidade maior da disseminação da infecção pelo HIV, trazem as conseqüências da interface da transmissão materno infantil.

\subsection{A TRANSMISSÃO MATERNO INFANTIL}

Estima-se que 15 a 30\% das crianças nascidas de mães soropositivas para o HIV adquirem o vírus na gestação, durante o trabalho de parto ou parto, ou por meio da amamentação (BRASIL, 2004b). As rotas possíveis para a transmissão vertical 
do vírus são: intra-útero transplacentária pela circulação materna, intraparto pela inoculação ou ingestão de sangue ou outros líquidos infectados, pós-parto via amamentação. A redução da taxa de transmissão vertical depende de intervenções que não devem ser direcionadas especificamente para a população sabidamente afetada pela epidemia de aids, mas oferecendo a todas as mulheres e crianças uma assistência de qualidade desde o pré-natal.

Apesar do oferecimento do exame sorológico para detecção da infecção pelo HIV e a distribuição gratuita da medicação anti-retroviral, no Brasil ainda existem dificuldades na identificação de gestantes soropositivas durante o pré-natal, fazendo com que muitas mulheres cheguem ao parto sem conhecer sua condição sorológica. Isto ocorre em parte devido ao baixo percentual de gestantes que realizam o prénatal no Brasil fato preocupante para o alcance das metas propostas pelo Ministério da Saúde. Em 2001 o percentual de nascidos vivos no país com mais de 6 consultas de pré-natal foi de 45,61\%; no estado de São Paulo, no mesmo ano, foi de 58,99\% (o melhor índice dentro da federação), sendo que no município de Ribeirão Preto foi de $74,34 \%$ (DATASUS, 2005).

Os estrangulamentos do sistema nacional de saúde estão se reproduzindo em todas as etapas do processo. Souza Júnior et al. (2004) referem que eles ocorrem desde a inclusão da gestante para o acompanhamento pré-natal até a ausência de pedido do teste sorológico para HIV e falta de conhecimento do resultado do teste antes do parto. Segundo a Coordenação Nacional de DST e Aids (CNDST/AIDS), a cobertura da testagem para o HIV durante o pré-natal está abaixo de 40\% (BRASIL, 2003a). Existem dificuldades da rede básica de saúde em prover diagnóstico laboratorial da infecção pelo HIV, trazendo, conseqüentemente, cobertura insuficiente de mulheres testadas no pré-natal. 
O teste utilizado para detecção de anticorpos anti-HIV no pré-natal é pelo método ELISA, que não permite resultados imediatos, prejudicando seu uso na identificação de pacientes que chegam às maternidades durante o trabalho de parto sem conhecimento de sua sorologia. Para esta finalidade foram desenvolvidos os "testes rápidos", que permitem a identificação das parturientes portadoras do vírus HIV que não apresentem exame sorológico anterior (DUARTE et al, 2001). Os testes rápidos para o HIV se mostraram altamente específicos, sensíveis, de baixo custo e de fácil execução (CARVALHO et al, 2004).

Em 1999, o Ministério da Saúde iniciou a distribuição gratuita do teste Determine $^{T M}$, que possibilita leitura em 15 minutos e a agilização da implementação das medidas profiláticas visando a redução da transmissão vertical do HIV. Ribeirão Preto foi um dos municípios onde, inicialmente, o teste foi distribuído às maternidades conveniadas com o Sistema Único de Saúde (SUS), possibilitando a identificação das gestantes soropositivas, inclusive aquelas que não fizeram o prénatal. A partir de 2002, o teste rápido passou a ser distribuído a todos os municípios brasileiros (BRASIL, 2002), permitindo maior agilidade na intervenção com os medicamentos anti-retrovirais (ARV).

A utilização adequada dos ARV e de outras medidas profiláticas da transmissão vertical modificaram o panorama da epidemia em crianças reduzindo efetivamente o número de casos.

Em agosto de 1994, os Centers for Disease Control and Prevention (CDC) de Atlanta - Estados Unidos - recomendaram o uso de zidovudina (AZT) em gestantes, baseado no Protocolo 076 desenvolvido pelo Aids Clinical Trials Group (ACTG). O estudo realizado em 1994 demonstrou que o uso de AZT, por gestantes assintomáticas durante a gestação e trabalho de parto e pelo recém-nascido, reduz 
o risco da transmissão vertical (CONNOR et al., 1994). O uso combinado de determinadas intervenções pode reduzir essas taxas para cifras menores que $1 \%$ (BRASIL, 2003b).

Baseado no protocolo ACTG 076, o Ministério da Saúde implementou as medidas de prevenção e apesar das dificuldades, nos últimos anos a incidência de casos de aids em crianças vem decrescendo progressivamente em nosso país. Em 2003 foi lançada nova edição do Guia de Tratamento - Recomendações para a Profilaxia da Transmissão Vertical do HIV e Terapia Anti-retroviral em Gestantes (BRASIL, 2003b), revisado, e cujas principais recomendações consistem em:

1. oferecer o teste anti-HIV a toda gestante, com aconselhamento pré e pósteste, independentemente da situação de risco da mulher;

2. ao ser feito o diagnóstico de infecção pelo HIV durante a gestação, a paciente deverá ser encaminhada para os serviços de referência na qual fará o seu acompanhamento pré-natal e clínico.

3. oferecer a terapia anti-retroviral oral a toda gestante infectada pelo HIV, de acordo com os critérios clínicos e laboratoriais visando o controle de sua infecção, devendo o tratamento ser iniciado em qualquer momento a partir da $14^{\mathrm{a}}$ semana de gestação até o parto;

4. as mulheres que já vinham recebendo $A R V$ previamente à gestação devem ser informadas sobre os potenciais riscos e benefícios da manutenção ou modificação do tratamento, considerando a evolução de sua doença e os efeitos adversos sobre a criança;

5. administrar AZT injetável à parturiente desde o início do trabalho de parto até o clampeamento do cordão umbilical, que deve ser realizado o mais rápido possível, após a expulsão da criança; 
6. a escolha da via de parto deve ser feita baseada na carga viral materna, sempre com o manejo adequado;

7. oferecer o AZT à criança, na sua forma de solução oral. Essa terapia deve-se iniciar nas primeiras 8 horas após o nascimento, e mantida até a sexta semana de vida (42 dias). Até o momento, não há comprovação de eficácia do medicamento, quando o tratamento é iniciado 48 horas após o nascimento;

8. orientar as mulheres infectadas quanto ao risco da transmissão do vírus durante a amamentação, e proceder a supressão farmacológica ou mecânica da lactação, usando substitutos do leite materno. É contraindicado o aleitamento cruzado.

9. assegurar o acompanhamento da criança por pediatra capacitado para o atendimento de crianças verticalmente expostas ao HIV, em ambulatório especializado.

É comum após o parto ocorrer a diminuição da adesão da mulher ao acompanhamento médico, devendo-se monitorar o seu comparecimento às consultas e fazendo busca ativa, se necessário. É recomendado que a mulher seja orientada quanto à importância do seu acompanhamento clínico e ginecológico e do acompanhamento da criança até a definição de sua situação sorológica; esta recomendação deve ocorrer durante todo o pré-natal e reforçada na alta do puerpério.

"Aquelas que se revelarem infectadas deverão permanecer em atendimento nessas unidades, ao passo que as não infectadas poderão ser encaminhadas para acompanhamento em unidades básicas de saúde. Nos centros de atendimento em países 
desenvolvidos, tem sido recomendado que mesmo as crianças não infectadas realizem visitas periódicas, até o final da adolescência em unidades especializadas, em virtude de terem sido expostas não só ao HIV, mas também durante o período intra-uterino, a drogas antiretrovirais. Essa preocupação reside no fato de não se saberem as possíveis repercussões da exposição a tais medicamentos a médio e longo prazo".(BRASIL, 2004b, p.10).

Os métodos que identificam a presença de anticorpos contra o HIV, como ELISA, Western Blot e Imunofluorescência Indireta, tem a sua interpretação prejudicada em crianças com idade inferior a 18 meses, devido à passagem transplacentária de anticorpos maternos (IgG anti-HIV). Deste modo todas estas crianças apresentam sorologia anti-HIV positiva ao nascimento; porém, somente cerca de 15 a 30\% delas estão infectadas quando nenhuma ação do protocolo ACTG 076 foi implementada (MARQUES, 2001). O diagnóstico definitivo requer o emprego de métodos específicos como o co-cultivo viral, a reação de polimerase em cadeia (PCR) e a pesquisa de antígeno p24 com acidificação.

O diagnóstico da infecção pelo HIV em crianças menores de 18 meses é determinado após a confirmação positiva em duas amostras de sangue, de exames realizados com os métodos específicos. Em crianças com idade igual ou superior a essa, a confirmação ocorre por meio de dois resultados reagentes pelo método ELISA, em duas amostras de sangue coletadas em momentos diferentes e pelo menos um teste confirmatório (BRASIL, 2004b).

Em virtude da contra-indicação do aleitamento materno, a CNDST/Aids recomenda o aleitamento artificial, com o fornecimento de fórmula láctea para a criança por 12 meses (BRASIL, 2004b). Se a criança for amamentada pela mãe HIV 
positiva, ela deve ser submetida à nova rotina diagnóstica, pois se considera que ocorreu nova exposição ao risco.

O acompanhamento dessas crianças deve ser mensal ou bimensal nos primeiros 6 meses, e trimestral a partir do segundo semestre de vida. A avaliação sistemática de seu crescimento e desenvolvimento é extremamente importante visto que as crianças, quando infectadas, podem, já nos primeiros meses de vida apresentar dificuldade de ganho de peso. Além disso, as crianças nascidas de mães infectadas pelo HIV também podem ter maior risco de exposição a outros agentes infecciosos como os vírus das hepatites B e C, o Treponema pallidum e o citomegalovírus. "O reconhecimento precoce e o tratamento de possíveis coinfecções devem ser prioritários no atendimento dessas crianças, devendo tal abordagem ser incluída em suas primeiras consultas". (BRASIL, 2004 b, p.12).

No acompanhamento também é importante um roteiro de exames laboratoriais para as crianças expostas, uma vez que deve ocorrer um monitoramento de efeitos adversos devido à exposição intra-uterina e pós-natal aos ARV, bem como da importância da identificação precoce das repercussões sistêmicas da infecção pelo HIV.

Se a criança estiver infectada, ela será mais susceptível não apenas a uma maior freqüência de infecções como também a agentes pouco comuns. A pneumonia por $P$. carinii é a mais freqüente infecção oportunista em crianças com aids, sendo a faixa etária de maior risco aquela compreendida entre os 3 e 6 meses de idade. Como a doença pode se manifestar e causar insuficiência respiratória aguda de alta letalidade, é indicada a profilaxia primária com o uso de sulfametoxazol e trimetroprima até completar um ano, ou até a definição do diagnóstico de não infecção (BRASIL, 2004b). 
Um acompanhamento sistemático dessas crianças deve ocorrer mesmo após a confirmação da sorologia negativa, uma vez que elas foram expostas a agentes com potenciais carcinogênicos (EL BEITUNE et al, 2004).

As medidas preventivas do protocolo ACTG 076 têm apresentado resultados efetivos na diminuição da transmissão vertical como comprovam os estudos de Tambeiro (2001); Kato (2002) e Nishimoto, Eluf Neto e Rozman (2005), entre outros.

\subsection{O MUNICÍPIO DE RIBEIRÃO PRETO}

O município de Ribeirão Preto localiza-se na região norte/nordeste do Estado de São Paulo, com uma população de 505.520 habitantes segundo o censo realizado pelo Instituto Brasileiro de Geografia e Estatística em 2000. É o município sede de uma região que compreende quase 1.000 .000 habitantes, e que atrai migrantes de outras partes do país para tentarem uma oportunidade de trabalho geralmente no corte da cana de açúcar. É também pólo regional em saúde dispondo de universidades (pública e privadas) com cursos na área de saúde e uma extensa rede de serviços públicos municipais: 35 Unidades Básicas e Distritais de Saúde, 1 Ambulatório Regional de Especialidades, 1 Centro de Referência em DST/Aids, 5 Unidades de Atendimento em Saúde Mental e 17 equipes do Programa de Saúde da Família. Em relação à rede hospitalar, são 2 hospitais públicos, sendo um deles o hospital universitário de referência terciária - Hospital das Clínicas da Faculdade de Medicina de Ribeirão Preto da Universidade de São Paulo (HCFMRP-USP) - e o outro para internações psiquiátricas. Ainda dispõe de 4 hospitais filantrópicos conveniados com o SUS, 2 hospitais privados/conveniados com o SUS e 3 hospitais 
privados, além de inúmeros serviços de caráter ambulatorial (RIBEIRÃO PRETO, 2004a). No que diz respeito ao atendimento dos portadores de HIV/aids, a rede está articulada nos 3 níveis de assistência, contando com ambulatórios municipais (inseridos nas unidades distritais de saúde), laboratórios e hospital de referência (HCFMRP-USP, local onde se realiza o atendimento às gestantes e crianças).

De acordo com os dados do Ministério da Saúde, Ribeirão Preto é a sétima cidade brasileira entre as que têm maior número de casos acumulados de aids, com 4729 no período de 1980 a junho de 2004; e a décima-sétima com maior incidência em aids (48,8 por 100.000 habitantes), ocorrendo uma queda nessa taxa após um longo período em que ficou entre as cinco primeiras (BRASIL, 2004a).

O primeiro caso da região de Ribeirão Preto foi registrado no Ministério da Saúde em 1986. O início da epidemia foi marcado pela predominância das categorias de exposição dos usuários de drogas injetáveis (UDI) e de UDI associados com outras categorias se mantendo dessa forma até 1997. Atualmente a categoria de exposição que se sobressai é a sexual, com predomínio dos heterossexuais, cuja curva ascendente chama a atenção pela feminização da epidemia. Dos 1245 casos notificados de adultos do sexo feminino até outubro de 2004, 83\% estão na faixa etária dos 15 a 39 anos (RIBEIRÃO PRETO, 2004b), ou seja, em plena fase reprodutiva, podendo engravidar e aumentando o risco da transmissão vertical do HIV.

$\mathrm{Na}$ rede básica de saúde do município, a sorologia anti-HIV foi institucionalizada pelo Programa Municipal de DST/Aids no ano de 1996, onde passou a ser oferecida às gestantes no início do pré-natal, em todas Unidades de Saúde (NEVES, 2003). Em caso de resultado positivo, ela é encaminhada ao HCFMRP-USP que é a referência para o atendimento destas gestantes, onde então 
realiza o pré-natal, parto e seguimento de puerpério no Ambulatório de Moléstias Infecciosas em Ginecologia e Obstetrícia - AMIGO. Após o parto, os respectivos recém-nascidos são acompanhados até os 18 meses de vida no Ambulatório de Moléstias Infecciosas em Berçário (AMIB); depois desse período, ele recebe alta ou é encaminhado para o Ambulatório de Infectologia em Crianças e Adolescentes (AICA) para seguimento.

Ainda na maternidade as mulheres são medicadas com Cabergolina para supressão da amamentação. Também são orientadas da importância do seguimento, do uso da medicação anti-retroviral na criança e quanto aos cuidados normais com o recém nascido - banho, preparo da mamadeira, limpeza do coto umbilical, entre outros. Na alta hospitalar já é assegurado o agendamento no AMIB para o seguimento da criança e fornecido 2 latas de leite em pó.

Embora o HCFMRP-USP seja o hospital de referência para atendimento das gestantes portadoras do HIV, eventualmente ocorre o parto de algumas dessas gestantes em outros hospitais do município. Isso acontece geralmente quando a gestante não tem a informação do resultado do teste anti-HIV (por não ter realizado pré-natal ou por não portar a carteira de gestante devidamente preenchida na chegada à maternidade). Neste caso, ela é detectada no teste rápido e os procedimentos são implementados. Antes da alta hospitalar é realizado o agendamento da mãe e da criança no HCFMRP-USP, e fornecido o leite através de contato com a Secretaria Municipal da Saúde (SMS). No ano de 2004, nasceram 49 crianças filhas de mães portadoras do HIV, residentes em Ribeirão Preto, sendo que houve um parto domiciliar e três nascimentos ocorreram em outras maternidades.

A SMS, através do Programa de Saúde da Criança e do Adolescente, desenvolve desde 1996, um projeto de busca ativa de recém-nascidos de risco, 
denominado Floresce Uma Vida, cujos objetivos são "reduzir a mortalidade infantil no município e diminuir a incidência e a gravidade de deficiências em crianças menores de um ano" (RIBEIRÃO PRETO, 1995). Por meio das ações do Floresce uma Vida, são promovidas atividades de vigilância do crescimento e desenvolvimento durante o primeiro ano de vida para todas as crianças residentes no município. Uma das estratégias para atingir os objetivos é a visita diária às maternidades SUS, procedendo orientações para todas as puérperas e garantindo o agendamento de puericultura nas unidades básicas de saúde. Assim, a equipe desse programa, mantém contato permanente com as equipes das maternidades, estabelecendo uma ponte entre o hospital e a rede básica de saúde, incluindo os ambulatórios especializados quando necessário (ambulatório de cardiologia pediátrica, de fissura lábio-palatal, de infectologia, de estimulação precoce, e outros).

No caso das crianças nascidas de mães soropositivas para o HIV, é preconizado a busca ativa, vigilância e monitoramento dessas crianças. Dessa forma, quando nasce uma criança filha de mãe portadora do HIV em outros hospitais (que não são referência), ela é imediatamente identificada pela equipe do Floresce uma Vida, que desencadeia o processo: comunica o Serviço Social da SMS para que seja encaminhado o leite à criança, solicita à Vigilância Epidemiológica o provisionamento de vacinas especiais, comunica a enfermeira da unidade de saúde mais próxima da residência da mãe para que esta realize visitas domiciliares periódicas, posteriormente verifica se houve comparecimento ao AMIB.

Entretanto, como ações importantes para prevenção da transmissão vertical se realizam durante a gestação, em 2003 juntamente com o Programa Municipal de DST/aids, iniciou-se a implementação da vigilância da gestante soropositiva. Por meio de visitas domiciliares, enfermeiras das UBS verificam se as gestantes que 
foram encaminhadas ao HCFMRP-USP estão fazendo o seguimento regular no AMIGO. Esta vigilância ainda não se efetivou em todas as unidades de saúde devido a problemas de recursos humanos e até mesmo pela falta de viatura para realizar as visitas domiciliares.

\subsection{A ADESÃO ÀS MEDIDAS PREVENTIVAS DA TRANSMISSÃO MATERNO INFANTIL}

O protocolo com as recomendações da profilaxia da transmissão materno infantil já está bem definido e de modo geral, os profissionais especializados estão bem capacitados para promover as orientações. Entretanto, no que diz respeito à adesão da mulher, poucos estudos têm sido desenvolvidos nesse sentido.

Com o advento da terapia anti-retroviral e principalmente das medidas do protocolo ACTG 076 emergiu a questão da adesão ao tratamento. Muito tem sido relatado a respeito da adesão à terapia medicamentosa, que envolve grande quantidade de comprimidos, efeitos colaterais e dificuldade de horários (CARVALHO et al 2003; FIGUEIREDO et al 2001). Entretanto, no caso da prevenção da transmissão vertical, é relevante que a mãe seja aderente a todos os procedimentos necessários para diminuir os riscos da transmissão da infecção. Este acompanhamento só apresenta resultados com a participação efetiva da mãe, visto que ela é responsável pela criança e é quem realiza todos os cuidados. É necessário que as mães sejam aderentes ao seu tratamento e ao do recém-nascido, implementando todas as ações recomendadas pelos profissionais de saúde. 
Pela definição de Houaiss (2001, p.08), "adesão é aceitação, concordância", e aderir, é "o ato de apoiar, de aceitar uma idéia". A mãe só vai aderir ao tratamento preventivo, se estiver sensibilizada com a idéia de que a criança pode ser infectada e que, para evitar essa infecção, é necessário seguir todas as orientações dos profissionais de saúde.

Segundo Neves (2003, p.02),

"existem facetas sócio-econômicas e culturais arraigadas, difíceis de serem transpostas, que não serão trabalhadas apenas com informação e sim, em um contexto mais amplo, na formação do indivíduo, objetivando mudanças de atitudes e comportamentos".

A complexidade da aids envolve não somente o lado cognitivo, do conhecimento e da informação, mas também as mudanças de comportamento.

Outros fatores estão envolvidos na adesão. Concordamos com Tunala et al (2000) quando apontam que a adesão é um processo de aprendizado de como lidar com as dificuldades econômicas, sociais e individuais, uma vez que atualmente a população mais acometida pela infecção, tem sido procedente de classes sociais menos favorecidas, com baixo nível de escolaridade, confirmando a tendência da pauperização da epidemia. Se as mães vivem em um ambiente em que as dificuldades sociais são preponderantes, elas podem não priorizar o seguimento preventivo de saúde, seu e de outros familiares. Este fato é ainda mais presente quando não existem sintomas, e todos apresentam uma aparência saudável, não justificando a necessidade de cuidados, retornos, medicamentos e exames.

Jordan et al. (2000) realizaram um estudo de revisão da literatura sobre adesão aos medicamentos, e constataram que algum grau de não-adesão ocorre universalmente, tanto em países desenvolvidos como nos subdesenvolvidos, e 
mesmo em doenças que envolvem potenciais riscos de vida. São relacionados alguns fatores que têm sido associados com a adesão ao tratamento:

- fatores relacionados à pessoa - perfil socioeconômico, idade, depressão, isolamento social;

- fatores relacionados à doença - sintomas, gravidade, vantagens terapêuticas;

- fatores relacionados ao tipo de tratamento - tempo, tipo, efeitos colaterais;

- fatores relacionados ao serviço de saúde - relação médico-paciente, confiança no serviço.

Acreditamos que no caso da adesão às medidas de prevenção da transmissão materno infantil, todos estes fatores também estão presentes e podem se constituir em objetos de investigação.

\subsection{JUSTIFICATIVA}

É estimado que 15 a 30\% das crianças nascidas de mães portadoras do HIV adquiram o vírus durante o período gestacional e perinatal. Entretanto, a combinação das intervenções recomendadas para profilaxia da transmissão vertical do HIV reduziram as taxas de transmissão para cifras inferiores a 1\% (BRASIL, 2003b).

No entanto para ocorrer e manter a diminuição do risco de infecção, é necessário além de profissionais capacitados para acompanhamento da mãe e da criança, a participação efetiva das mães em realizar todas as intervenções recomendadas: comparecimento ao pré-natal, realização dos exames, aceitação das 
medicações e administração destas na criança, supressão da amamentação, seguimento da criança no ambulatório especializado. A adesão da mãe é fundamental para diminuir o risco da infecção na criança.

Foi por meio do Floresce uma Vida, como membro da equipe deste programa desde 1999, que tivemos contato com as crianças nascidas de mães soropositivas para o HIV, e na qual colaboramos nas capacitações dos enfermeiros para a vigilância do recém-nascido e da gestante soropositiva.

À medida que nos aproximamos das gestantes e crianças expostas sob vigilância, constatamos que algumas mães não fizeram o pré-natal adequadamente ou falharam em algum atendimento da criança. Por outro lado, a nossa prática profissional tem evidenciado que a maioria das mães segue sistematicamente o tratamento proposto para si e para o recém-nascido. Algumas reflexões emergiram destas constatações:

- as mães consideram que a aids é uma doença grave?

- elas acreditam que podem transmitir o vírus ao seu filho?

- as mães consideram que a adoção de medidas profiláticas pode trazer benefícios para a criança?

Estas inquietações nos motivaram a desenvolver este estudo em que buscamos compreender os fatores que influenciam na adesão das mães às medidas profiláticas da transmissão vertical do HIV.

Como referencial teórico, utilizamos o Modelo de Crenças em Saúde, visto que esse procura explicar a adoção de comportamentos preventivos e estabelecer relações entre o comportamento individual e algumas crenças individuais (DELA COLETA, 2004). 


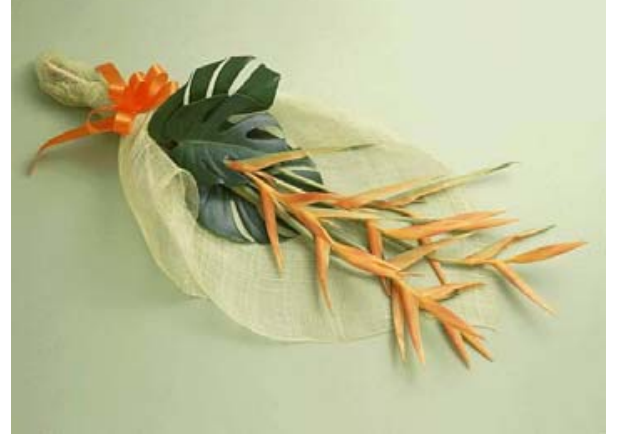

2. O6jetivos 


\section{OBJETIVOS}

\subsection{OBJETIVO GERAL}

$>$ Compreender as crenças que influenciam o comportamento das mães portadoras do HIV em relação à adesão às medidas profiláticas da transmissão materno infantil do vírus.

\subsection{OBJETIVOS ESPECÍFICOS}

Identificar as percepções de susceptibilidade e severidade da infecção pelo HIVlaids entre as mães soropositivas;

Identificar as percepções que estas mães apresentam acerca dos benefícios que a prevenção da transmissão vertical do HIV pode trazer à criança;

Identificar as barreiras que podem dificultar o processo de adesão às medidas profiláticas da transmissão vertical do HIV. 
3. O Modelo de Crenças em Saúde 


\section{O MODELO DE CRENÇAS EM SAÚDE}

Compreender as razões que levam as mães portadoras do HIV a aderirem às medidas profiláticas da transmissão vertical, significa compreender a influência dos fatores ambientais e psicossociais no comportamento destas mães. Dentre os fatores psicossociais, as crenças parecem influenciar diretamente nas atitudes dos seres humanos.

Para compreender essas atitudes, buscamos então, um modelo teórico que possibilitasse explicar o comportamento preventivo em saúde. A opção recaiu sobre o Modelo de Crenças em Saúde, o Health Belief Model, proposto por Rosenstock (1974) enquanto referencial teórico para nortear a análise dos dados.

O Modelo de Crenças em Saúde (MCS), segundo Janz e Becker (1984, p.1) é considerado “(...) o principal modelo para explicar e predizer a aceitação de recomendações sobre cuidados com a saúde".

Este modelo foi desenvolvido no início da década de 50 por um grupo de psicólogos sociais do Serviço de Saúde Pública dos Estados Unidos, para tentar explicar porque as pessoas não se preveniam corretamente contra certas doenças para as quais já havia vacinas ou testes, tais como a poliomielite ou a tuberculose (DELA COLETA, 2004).

Ele foi originalmente formulado por Hochbaum, Leventhal, Kegeles e Rosenstock e publicado por Rosenstock em 1966, para explicar a ação preventiva tentando especificar as variáveis que parecem contribuir para se compreender o comportamento na saúde. Posteriormente foi aplicado a comportamentos 
relacionados à manutenção da saúde em geral, incluindo o atendimento correto às recomendações médicas.

O cerne básico do modelo refere-se à crença de que toda conduta é motivada. A partir desta compreensão, esperavam poder entender e controlar o comportamento humano, identificando as suas motivações.

Maiman e Becker (1974) consideram o modelo como uma aplicação de teorias psicológicas de tomada de decisão e alternativas comportamentais sobre saúde, considerando, entretanto a Teoria de Campo de Kurt Lewin como originária do Modelo de Crenças.

Rosenstock (1974) fez uma revisão do MCS aplicado ao comportamento preventivo e destacou os conceitos elaborados por Kasl e Cobb (1966) aos diferentes comportamentos, denominados comportamentos de saúde, quais sejam:

Comportamento na saúde é "qualquer atividade empreendida por uma pessoa que acredita estar saudável, com o intuito de prevenir doenças ou detectá-las em um estágio assintomático".

Comportamento frente ao sintoma é "qualquer atividade de uma pessoa que se sente doente, com o propósito de definir seu estado de saúde e de descobrir o remédio adequado".

Comportamento na doença "refere-se à atividade empreendida por aqueles que se consideram doentes, com o propósito de curar-se".

Esses comportamentos ocorrem de forma contínua, entrelaçando-se, embora as distinções entre eles sejam importantes, quando se consideram as diversas concepções inerentes a cada situação. O primeiro caso está relacionado ao desejo de se evitar a doença e continuar saudável; a distinção nos dois últimos casos é que uma pessoa frente a um sintoma pode procurar o médico para conhecer o 
diagnóstico e decidir não fazer o tratamento por motivos pessoais, como o alto custo do mesmo ou ainda porque a doença é vista como incurável (DELA COLETA, 1995).

Rosenstock (1974) propôs o MCS para melhor apreensão dos fatores que influenciam a percepção das pessoas acerca das crenças e para elaboração de um planejamento mais efetivo dos cuidados voltados à manutenção da saúde.

As características preliminares do MCS consideram que para um indivíduo adotar medidas preventivas, ou seja, evitar doenças, ele necessariamente precisa acreditar em três aspectos: ele é susceptível à doença; que a ocorrência da doença deverá acarretar pelo menos alterações moderadas em alguns componentes de sua vida; que a tomada de determinada ação deverá ser benéfica, reduzindo sua susceptibilidade à referida condição, diminuindo sua gravidade e desvinculando-a de barreiras mais importantes, tais como custo, conveniência, dor, embaraço.

Para apreensão do significado de comportamento preventivo, é necessário entender uma ampla variedade de ações preventivas que demonstre como elas estão inter-relacionadas. Quando o comportamento refere-se de maneira moderada e não totalmente à saúde, a alteração pode estar voltada para a variável crença sobre a doença. A crença pode variar de pessoa para pessoa, apresentar-se diferente em uma outra pessoa, de doença para doença, mas o importante é tentar identificar que fatores estão concorrendo para essa diversificação de ações em saúde. Embora a tomada de ação preventiva seja um ato voluntário, nota-se que as pessoas são motivadas por sua própria decisão; então, como a motivação é individual, a tomada de decisão em saúde está baseada na crença individual, Isto é, no grau de percepção e motivação que a pessoa tem sobre uma determinada realidade (LESCURA; MAMEDE, 1990). 
Segundo Bowers (1980), o MCS baseia-se nas percepções do paciente acerca de sua situação de saúde e não na dos profissionais de saúde. De acordo com Rosenstock (1974), o MCS é composto basicamente de quatro dimensões:

- Susceptibilidade percebida - refere-se à percepção subjetiva do risco pessoal de contrair uma doença;

- Severidade percebida - a gravidade ou seriedade da doença pode ser avaliada tanto pelo grau de perturbação emocional criado ao pensar na doença quanto pelos tipos de conseqüências que a doença pode acarretar: dor, morte, gasto material, interrupção de atividades, perturbações nas relações familiares e sociais;

- Benefícios percebidos - referem-se à crença na efetividade da ação e à percepção de suas conseqüências positivas;

- Barreiras percebidas - os aspectos negativos da ação são avaliados em uma análise do tipo custo-benefício, considerando possíveis custos de tempo, dinheiro, esforço, aborrecimentos, etc.

Para Dela Coleta (2004, p. 30),

"O potencial para a ação é resultado dos níveis combinados de susceptibilidade e de severidade percebidas na doença, enquanto a modalidade de ação é escolhida em função da percepção dos benefícios, menos as barreiras percebidas nas alternativas comportamentais. (...) Outras variáveis podem afetar a percepção individual influenciando indiretamente a ação final. São os fatores biográficos, psicossociais e estruturais, elementos cuja interação com os demais está reproduzida graficamente na figura 1". 


\section{Modelo de Crenças em Saúde}

\section{Percepções Individuais}

\section{Fatores Modificadores}

\section{Probabilidade de ação}

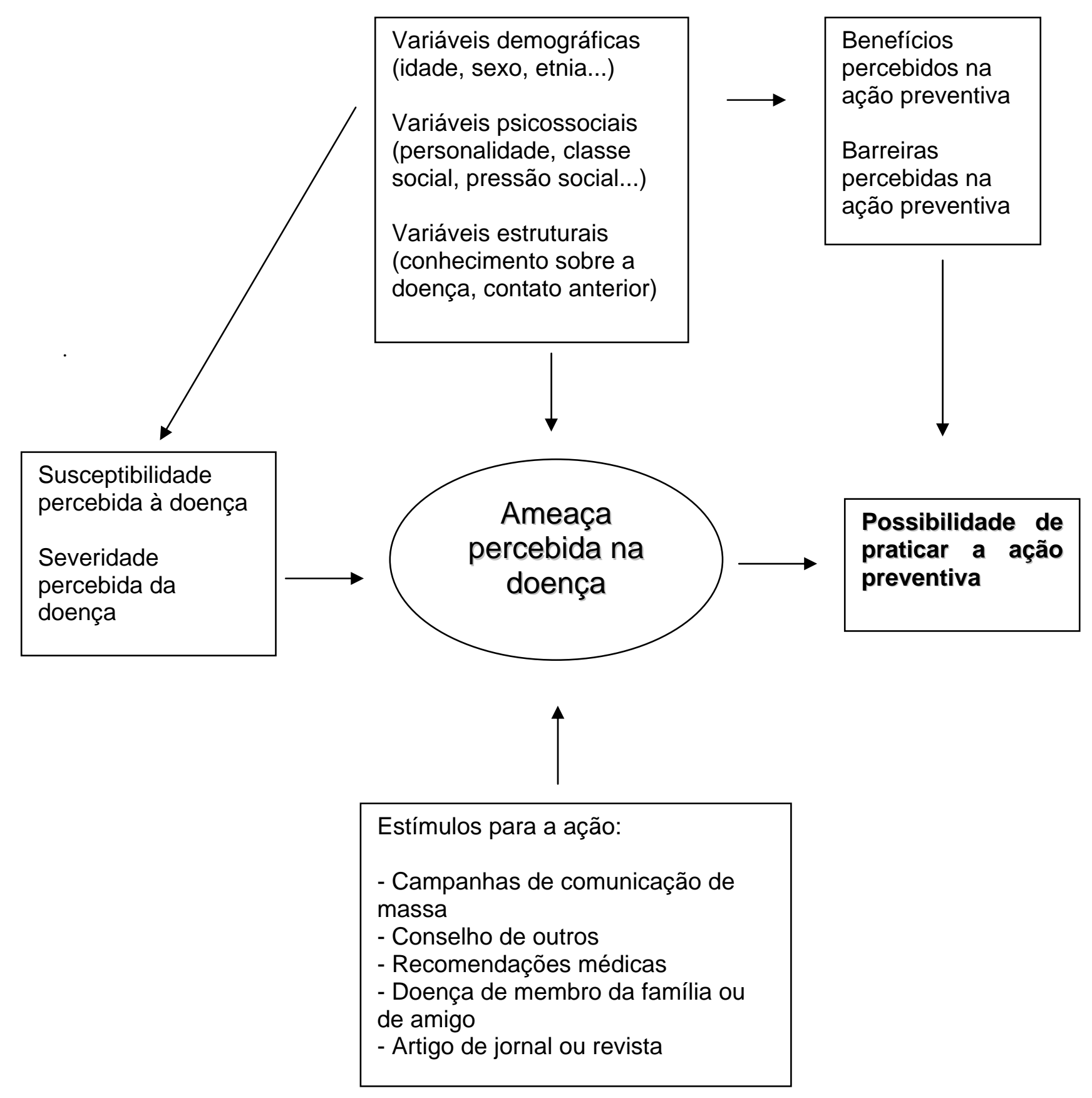

Figura 1: Modelo de Crenças em Saúde como preditor do comportamento preventivo, segundo Rosenstock (1974). 
Rosenstock (1974), como já referido, fez uma revisão dos estudos sobre MCS e prevenção, analisando criticamente esse modelo já que nos primeiros estudos não fizera formulação do conceito motivacional. Para o autor, a motivação é uma condição necessária para ação e o indivíduo seleciona a motivação segundo a determinação das percepções do ambiente. Em 1974, Becker, Drachman e Kirscht publicaram estudo sobre a aplicação do MCS na detecção da doença de Tay-Sachs, doença genética grave que pode ser diagnosticada intra-útero através do exame do líquido amniótico. Esta foi, segundo Rosenstock (1974), a primeira vez que a motivação para a saúde foi introduzida no modelo para explicação de um comportamento preventivo.

Rosenstock (1990) cita outras variáveis que podem atuar como fatores modificadores das percepções dos indivíduos em algum momento: demográficas, como idade, sexo, nível educacional, raça, etc.; sócio-psicológicas, como classe social, personalidade, pressão do grupo social; e estruturais, como conhecimento, contato anterior com a doença, crenças e valores. Tais variáveis podem modificar a percepção dos benefícios e barreiras às ações preventivas, influenciando indiretamente o comportamento do indivíduo em relação à saúde.

Em uma revisão realizada em 1984, Janz e Becker avaliaram 29 estudos desenvolvidos entre 1974 e 1984, e observaram que os melhores resultados foram obtidos com a variável "barreiras", seguido de "benefícios", "susceptibilidade" e "severidade", nesta ordem.

Este modelo vem sendo aperfeiçoado desde 1984, e também vem ocorrendo uma crescente aplicação do mesmo em diversos estudos, de diferentes áreas, principalmente na enfermagem, psicologia e medicina, relacionadas a moléstias e condutas em saúde (DELA COLETA, 2004). A partir das formulações do modelo, 
pesquisadores têm utilizado o MCS com adaptações de acordo com os objetivos propostos.

Neste estudo pressupomos que as mães que aderem às medidas profiláticas da transmissão vertical do HIV temem que seu filho seja infectado com o vírus, pois sabem que é uma doença grave, e que apesar de ter um tratamento que a controle, ainda é considerada incurável. Em vista disso, as mães atribuem que a adesão a essa prática apresenta mais benefícios do que barreiras.

Dela Coleta (2004, p.52), aponta que:

"O pesquisador que se preocupar em saber como pensa cada indivíduo, se considerar as variáveis do MCS e incluir outras tão importantes e específicas ao estudo, estará no caminho certo para encontrar respostas para o problema de saúde que vem a ser a não adesão aos comportamentos de prevenção, tratamento ou controle das doenças".

Portanto, consideramos que a fundamentação teórica escolhida é adequada uma vez que o MCS representa uma alternativa importante para os estudiosos que visam pesquisar ou intervir em saúde e avaliar a influência dos fatores subjetivos sobre o comportamento dos indivíduos. 


\section{Percurso metodológico}




\section{PERCURSO METODOLÓGICO}

Trata-se de um estudo descritivo de natureza qualitativa. A abordagem qualitativa enfatiza o mundo dos significados das ações e relações humanas, um aspecto não perceptível ou captável quantitativamente (MINAYO, 1999). Desta forma, a utilização da pesquisa qualitativa pode responder a questões específicas, em um contexto de realidade que não pode ser quantificado.

A pesquisa qualitativa trabalha com o universo dos significados, crenças, valores, motivos, aspirações, e atitudes, correspondendo a um espaço mais profundo dos processos, das relações, e dos fenômenos que não podem ser reduzidos à operacionalização de variáveis (MINAYO, 1999).

Assim, acreditamos que o método qualitativo conduzirá ao aprofundamento dos questionamentos que motivaram este estudo, permitindo uma compreensão mais ampla do objeto.

O referencial teórico utilizado é o Modelo de Crenças em Saúde, conforme descrito no capítulo anterior.

\subsection{POPULAÇÃO E AMOSTRA}

A população alvo do estudo constituiu-se de mulheres portadoras do HIV, cuja gravidez resultou em nascimento de criança viva no município de Ribeirão Preto no ano de 2004. Os critérios considerados para inclusão no estudo foram: 
ser soropositiva para o HIV;

o parto ter ocorrido em Ribeirão Preto;

a mãe estar em boas condições físicas, biológicas, psíquicas e emocionais; ter aquiescido em participar da pesquisa;

a criança estar com pelo menos seis meses de vida;

residir no município de Ribeirão Preto no momento da coleta dos dados;

a criança estar sob os cuidados da mãe.

Foram excluídas as mães que não estão com a guarda de suas crianças, ou seja, cujas crianças estão sob os cuidados de avós, tias, e outros parentes ou instituições de abrigo.

A população do estudo foi levantada através do banco de informações do Programa Floresce Uma Vida da SMS de Ribeirão Preto. No ano de 2004 ocorreu o nascimento de 49 crianças filhas de mulheres soropositivas ao HIV, das quais 20 atendiam aos critérios de inclusão no momento da coleta dos dados. Porém, não conseguimos localizar o endereço de 5 dessas mulheres e uma se recusou a participar do estudo, ficando a amostra composta por 14 mulheres.

\subsection{COLETA E ORGANIZAÇÃO DOS DADOS}

\subsubsection{Instrumento para coleta de dados}

Para o desenvolvimento do estudo, elaboramos um primeiro instrumento constituído por questões que requeriam respostas abertas e fechadas. Realizamos 
um teste com mulheres que tiveram filhos no ano de 2003 , e solicitamos o auxílio de 2 profissionais peritos em ensino, pesquisa e assistência, para que atuassem enquanto juízes para validação. Consideramos pertinente proceder algumas alterações em sua forma e conteúdo para melhor adequá-lo aos objetivos propostos e ao referencial teórico. Na segunda versão do instrumento, ele foi testado novamente e considerado adequado à proposta.

O instrumento foi dividido em 2 partes, sendo que a primeira constou da caracterização das participantes - idade da mãe e da criança, ocupação, renda familiar, escolaridade, número de filhos, parceria sexual, descoberta do HIV em relação a esta gestação, forma de infecção, realização de pré-natal, local do parto e sorologia do RN. A segunda parte foi composta de questões norteadoras com base no referencial teórico e que foram agrupadas de acordo com as 4 dimensões do modelo de crenças: percepção de susceptibilidade, percepção da severidade, benefícios percebidos e barreiras percebidas (Anexo 1).

\subsubsection{Procedimentos para coleta de dados}

Para a coleta de dados das mulheres estudadas, empregamos a técnica de entrevista semi-estruturada gravada, norteada pelo instrumento específico. A opção pela entrevista semi-estruturada ocorreu por esta nos possibilitar maior flexibilidade e profundidade (GOLDENBERG, 1999). Entendemos por entrevista semiestruturada, em geral, 
“...aquela que parte de certos questionamentos básicos, apoiados em teorias e hipóteses, que interessam à pesquisa, e que, em seguida, oferecem amplo campo de interrogativas, fruto de novas hipóteses que vão surgindo à medida que se recebem as respostas do informante" (TRIVINOS, 1987, p.146).

As entrevistas foram realizadas na residência das mulheres, em visitas domiciliares realizadas pela própria pesquisadora. A coleta de dados por meio de visitas domiciliares favorece o contato com a clientela fora dos serviços de saúde, possibilitando acrescentar informações que caracterizam as condições sociais das mães. Na medida do possível, estas visitas eram previamente agendadas de acordo com a disponibilidade de ambas as partes. Cada entrevista durou em média 40 minutos, algumas se estendendo até 60 minutos e foram realizadas no período de novembro/2004 a janeiro de 2005.

Vale ressaltar que esta etapa foi permeada por algumas dificuldades principalmente relacionadas à localização da residência das mulheres. Como os endereços foram levantados a partir dos dados do parto, ocorreram casos de mudança de residência, inclusive para outras cidades, e até mesmo endereço inexistente. Dessa forma, na amostra de 14 mães ocorreu uma coincidência, que foi o fato de que todas as entrevistadas estavam fazendo o seguimento da criança em ambulatório especializado, embora 2 não tivessem feito o pré-natal.

No momento da visita, apresentávamos a elas os objetivos da pesquisa e o destino dos dados obtidos; logo após, era realizada a leitura do termo de consentimento livre e esclarecido, como também lhe era assegurado o sigilo e a confidenciabilidade dos dados. As mulheres também foram informadas de que poderiam se sentir à vontade para solicitar qualquer esclarecimento, garantindo-Ihes 
o respeito ao anonimato e à liberdade de recusa em participar da mesma. Todas as participantes autorizaram o uso do gravador e assinaram o termo de consentimento, à exceção de uma, que fez sua autorização verbalmente, por ser analfabeta. Após esses esclarecimentos iniciávamos a entrevista que era gravada e transcrita no mesmo dia.

Para garantir o anonimato das participantes, os nomes foram substituídos por nomes de flores. Esta opção se deve ao fato de que, na natureza, a flor carrega e protege a semente que vai germinar novos jardins e propagar a espécie. Assim consideramos as mães, pois "carregam" e "cuidam" de seus filhos, perpetuando a família e a espécie humana.

\subsubsection{Organização dos dados para análise}

Após cada visita, as entrevistas gravadas eram transcritas integralmente e digitadas no mesmo dia pela própria pesquisadora.

Os dados quantitativos foram registrados e descritos de forma que evidenciassem um perfil das mulheres que compuseram a amostra, uma vez que foram coletados apenas para compor o cenário, onde foi feito o trabalho qualitativo.

Com relação aos dados qualitativos, utilizamos o método da Análise de Conteúdo, preconizada por Bardin (1979). Esse método é definido como "um conjunto de técnicas de análise das comunicações, visando, por procedimentos sistemáticos e objetivos de descrição do conteúdo das mensagens, obter indicadores que permitam a inferência de conhecimentos relativos às condições de 
produção/recepção das mensagens". O método compõe-se das fases de préanálise, exploração dos dados e tratamento e interpretação dos resultados.

Durante a pré-análise realizamos a leitura flutuante e superficial dos depoimentos. Após essa leitura, fizemos uma aproximação maior dos dados, com leitura aprofundada, dando início à fase de exploração, e onde os conteúdos recorrentes e contraditórios espontaneamente emergiam.

As unidades de análise foram sendo selecionadas, codificadas e inseridas nas dimensões do referencial teórico: susceptibilidade percebida, severidade percebida, benefícios percebidos e barreiras percebidas. Continuando essa etapa de exploração, emergiram categorias, que foram interpretadas com base no significado atribuído por Rosenstock.

A categorização foi feita agrupando-se as falas que apresentavam significados semelhantes, mesmo que tivessem conotações distintas ou contraditórias. O nome atribuído a cada subcategoria foi definido no término da etapa, considerando-se o tema abordado nos significados das falas.

\subsection{ASPECTOS ÉTICOS}

O projeto foi apreciado pelo Secretário Municipal da Saúde de Ribeirão Preto e pela Coordenadora do Ambulatório de Moléstias Infecciosas em Berçário do HCFMRP-USP e aprovado pelo Comitê de Ética da Escola de Enfermagem de Ribeirão Preto da Universidade de São Paulo (n 0403/2003, em anexo). 


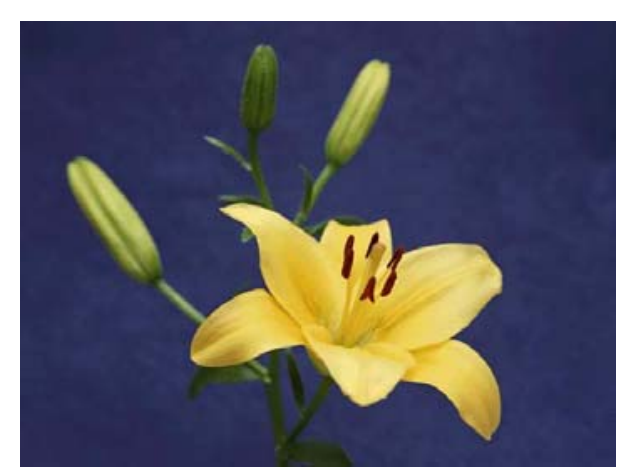

5. Apresentando e discutindo os resultados 


\section{APRESENTANDO E DISCUTINDO OS RESULTADOS}

Os conteúdos advindos do material coletado foram trabalhados, tendo como finalidade revelar as nuances do objeto de estudo, tornando possível a apreensão e compreensão da realidade estudada. Para tanto, apresentamos inicialmente uma breve descrição de cada uma das entrevistadas que tem a finalidade de situar o leitor no contexto individual de vida; posteriormente foi traçado um perfil conjunto dos dados sócio-demográficos investigados.

Por fim, descreveremos as categorias emanadas das falas das participantes, e interpretadas à luz do Modelo de Crenças em Saúde (MCS) proposto por Rosenstock.

\subsection{BREVE DESCRIÇÃO DAS PARTICIPANTES}

\section{Lírio}

Lírio tem 32 anos, do lar, 5 filhos sendo 2 do primeiro companheiro e 3 do atual, estudou até a oitava série, tem renda familiar de 2 salários mínimos, mora em conjunto habitacional na periferia da cidade. O atual parceiro é soropositivo para o HIV e acha que foi infectada por ele. Descobriu que era soropositiva durante o puerpério da quarta filha - não fez pré-natal devido ao trabalho em que se encontrava e achava que não tinha necessidade, uma vez que já era a quarta 
gestação. Após alguns dias ficou sabendo o resultado dos exames e a confirmação do HIV. A criança foi encaminhada ao ambulatório, mas, também já era positiva. Na investigação dos outros filhos, descobriu-se que a terceira filha também estava infectada - durante o pré-natal dela os exames foram negativos, mas a criança foi amamentada durante 3 anos e acredita que ela foi infectada na amamentação. Por um descuido, engravidou novamente, mas já ciente da necessidade do acompanhamento, fez o pré-natal regularmente e o recém nascido faz seguimento no ambulatório especializado. Esta criança tem o resultado negativo para o HIV.

\section{Tulipa}

Tulipa tem 35 anos, 13 filhos, sendo 2 do atual companheiro, é analfabeta e não tem ocupação fora de casa; a renda familiar é em torno de 1 salário mínimo, moram em um barraco com 2 cômodos no fundo de um quintal onde também moram sua mãe e sua irmã casada. O atual parceiro desconhece que ela é portadora do HIV e diz que não pretende contar. Soube da infecção há aproximadamente 6 anos, após um parto e depois desse já teve mais 3 gestações

e está grávida novamente (décima quarta gestação). Não acredita que tenha o vírus, não faz acompanhamento ambulatorial, nunca fez pré-natal e não levou os outros filhos ao ambulatório especializado. O recém nascido está em seguimento no HCFMRP-USP devido a uma complicação no parto e acha que por isso deve continuar levando-o ao médico. Informa que os exames dele são negativos. 


\section{Gerânio}

Gerânio tem 21 anos, do lar, 2 filhos, estudou até a sexta série, não trabalha e não sabe informar a renda familiar, mora em casa de alvenaria nos fundos na periferia da cidade. É casada e o marido é soronegativo; há cerca de 2 anos estiveram um período separados, durante o qual ela teve um outro parceiro, que acha que foi quem a infectou. Depois da reconciliação, engravidou e durante o pré-natal descobriu que era soropositiva para o HIV. Apesar da dificuldade inicial, recebeu apoio do marido, e está fazendo acompanhamento em ambulatório próximo à sua casa. O recém nascido faz seguimento no HCFMRP-USP, e os exames dele são negativos.

\section{Rosa}

Rosa tem 15 anos, estudou até a sétima série, tem um filho, mora com o namorado, a mãe e o irmão mais novo em um conjunto habitacional na periferia; refere que não têm renda devido estarem todos desempregados no momento. O parceiro é negativo, mas conhece a situação dela e da mãe que também é positiva para o HIV. Rosa refere que aos sete anos de idade teve pneumonia e diarréia, ficando internada muito tempo; foi quando descobriram que ela era portadora do vírus, investigaram a família e descobriram que a mãe e o irmão também eram, concluindo que foram infectados por via vertical. Desde então tem feito seguimento no ambulatório do HCFMRP-USP e faz uso de medicamentos anti-retrovirais. Fez pré-natal e o recém nascido está sendo acompanhado; os resultados dos exames dele são negativos. 


\section{Violeta}

Violeta tem 24 anos, um filho, estudou até a quinta série, trabalha como auxiliar de cozinha, é desquitada, teve um namorado que é o pai do seu filho, mas atualmente está sozinha. Mora com 2 irmãs e um cunhado em casa de alvenaria em bairro da região central da cidade; a renda familiar gira em torno de 5 salário mínimos. Durante a gravidez descobriu que era portadora do HIV, e acha que se infectou com o seu ex-marido. Fez o pré-natal no HCFMRP-USP, onde leva a criança para seguimento. Após o parto não procurou qualquer ambulatório para acompanhamento de sua infecção. Os resultados dos exames do recém nascido são negativos.

\section{Begônia}

Begônia tem 24 anos, um filho, estudou até a oitava série, não trabalha fora e mora com os pais em uma casa de fundos; a renda da família é de 3 salários mínimos. É solteira e atualmente está sozinha. Há 3 anos fez uma cirurgia para retirada de um rim e descobriu que era soropositiva para o HIV. Durante esta gestação não fez pré-natal, pois não queria acreditar que estava grávida, mas como já fazia uso de anti-retrovirais continuou tomando-os normalmente. Nunca conversou com o pai da criança a respeito da infecção pelo HIV. Leva o recém nascido para seguimento no HCFMRP-USP, onde também faz o seu acompanhamento. Os exames dele são negativos. 


\section{Margarida}

Margarida tem 23 anos, 2 filhos, estudou até o terceiro colegial, é casada e trabalha como doméstica. Mora em casa de alvenaria, em bairro periférico e a renda familiar é de 2 salários mínimos; o marido é soronegativo. Descobriu que era portadora do HIV durante a realização do pré-natal; acha que se infectou com o antigo namorado que é pai do primeiro filho. Depois do puerpério, iniciou acompanhamento no ambulatório próximo a sua casa, e continua levando o recém nascido no HCFMRP-USP; os resultados dos exames dele são negativos.

\section{Hortência}

Hortência tem 27 anos, estudou até a sexta série, tem 3 filhos e não trabalha fora. Mora em casa invadida de um conjunto habitacional na periferia e a renda familiar é de 1 salário mínimo. O primeiro marido morreu de aids há quatro anos, e o atual companheiro, pai do filho mais novo, também é soropositivo. Soube que era portadora do HIV durante a gravidez do segundo filho, há seis anos, quando então descobriu a doença do marido. Há três anos conheceu o atual parceiro em uma ONG de ajuda a soropositivos. Durante a última gestação fez o pré-natal no HCFMRP-USP, onde leva o recém nascido para seguimento; atualmente faz acompanhamento no ambulatório próximo a sua casa. Os resultados dos exames da criança são negativos. 


\section{Orquídea}

Orquídea tem 20 anos, 2 filhos sendo que um mora com a avó; estudou até a sexta série, não trabalha fora e reside em 2 cômodos de alvenaria nos fundos de um quintal na periferia. A renda mensal é de aproximadamente meio salário mínimo; há cinco meses está vivendo com um companheiro, que não é o pai do recém nascido e que desconhece a situação sorológica dela. Acha que se infectou com o ex-namorado, pai do seu filho e que a abandonou. Descobriu que era portadora durante a realização do pré-natal; ainda está fazendo acompanhamento no HCFMRP-USP, onde leva a criança para seguimento. Os resultados dos exames dele são negativos.

\section{Petúnia}

Petúnia tem 27 anos, do lar, 3 filhos, sendo a primeira adotiva, estudou até a quarta série, mora em uma casa de conjunto habitacional na periferia da cidade. A renda familiar é de um salário mínimo, é casada e o marido é portador do HIV. Descobriu que era infectada durante um pré-natal há dois anos, quando inclusive teve um aborto espontâneo. Nessa época, soube que o marido já conhecia a condição de soropositivo, mas não tivera coragem de lhe falar. Desde então, faz acompanhamento no ambulatório próximo a sua casa. Como queria ter um filho do sexo masculino, fez a opção de engravidar e fez o pré-natal no HCFMRP-USP; teve um parto difícil, com bolsa rota, complicações perinatais, e o recém nascido ficou internado por vários dias. Depois da alta, iniciou o seguimento do filho e logo Ihe disseram que ele estava infectado também. A criança apresenta displasia de 
pele, algumas complicações neurológicas e faz acompanhamento no HCFMRPUSP.

\section{Flor do campo}

Flor do campo tem 33 anos, 3 filhos, estudou até a quarta série, trabalha como diarista 2 vezes/semana; mora com a mãe, avó, 2 irmãos e os 3 filhos nos fundos da casa da ex-sogra; a renda familiar é de cerca de 2,5 salários mínimos. Teve 3 parceiros com os quais viveu em união consensual sendo, cada um, pai de um dos filhos. Com o último conviveu por cinco anos e após o nascimento do filho, se separaram. Durante o pré-natal descobriu ser portadora do HIV, conversou com o companheiro que se recusou a fazer o exame; acha que se infectou com o segundo parceiro, pois descobriu que ele tinha outras mulheres. Ela ainda não procurou o ambulatório especializado para seguimento, mas a criança está sendo acompanhada no HCFMRP-USP; os resultados dos exames dela são negativos.

\section{Calêndula}

Calêndula tem 37 anos, do lar, 2 filhos, estudou até a oitava série; mora em uma casa de conjunto habitacional na periferia. Está casada há 15 anos, é evangélica, a renda familiar é de 3 salários mínimos. O marido descobriu que era portador há 11 anos, quando ela estava grávida do primeiro filho, porém fez o exame e o resultado dela foi negativo. Depois de 2 anos, fez o exame novamente e deu positivo. Desde então faz acompanhamento no HCFMRP-USP e nesse período já apresentou várias internações; refere ter engravidado fazendo uso de pílula 
anticoncepcional, pois não gosta de usar preservativo. Leva o filho ao HCFMRPUSP e os resultados dos exames dele são negativos.

\section{Camomila}

Camomila tem 28 anos, 3 filhos, porém só o recém nascido está com ela (o primeiro com 10 anos mora com o pai em outra cidade e o segundo ela deu para adoção), teve mais quatro gestações sendo 2 abortos e 2 óbitos prematuros; estudou até a oitava série e mora sozinha com a filha em 2 cômodos nos fundos de um quintal. Trabalha como profissional do sexo na rua, tendo renda aproximada de 3 salários mínimos; paga uma babá para cuidar da menina enquanto trabalha; no momento não tem parceiro fixo. Depois da separação do marido há 5 anos resolveu fazer o exame devido ao fato dele ser usuário de drogas endovenosas e o resultado foi positivo; contou a ele que se recusou a fazer o exame. Veio trabalhar em Ribeirão Preto, grávida de 3 meses, fruto de um outro relacionamento que teve em São José dos Campos; logo procurou a UBS para fazer o pré-natal, de onde foi encaminhada ao HCFMRP-USP. Refere já ter iniciado acompanhamento clínico várias vezes, mas não deu continuidade. O recém nascido está em seguimento no HCFMRP-USP e os resultados dos exames são negativos.

\section{Jasmim}

Jasmim tem 23 anos, um filho, casada, tem formação universitária, renda familiar aproximada de 6 salários mínimos, mora com o marido e o filho em casa de 
alvenaria na região central. Descobriu que era soropositiva ao HIV durante o prénatal realizado em consultório particular; o marido fez exame e também é soropositivo. Refere que estão juntos há sete anos, e nunca namorou outra pessoa. Informa que o marido teve apenas uma namorada antes dela. Nunca conversaram sobre o assunto com os familiares e amigos, mas estão sempre buscando informações na internet, onde também conversam com outros portadores. Ela e o recém nascido estão fazendo acompanhamento em consultório particular, através de convênio médico, e os resultados dos exames dele são negativos.

\subsection{PERFIL SÓCIO-DEMOGRÁFICO}

A amostra estudada foi constituída por 14 mulheres portadoras do HIV, cujo parto ocorreu no município de Ribeirão Preto no ano de 2004.

No que se refere à idade, o intervalo expresso pelo grupo variou de 15 a 37 anos, com a idade média de 26,4 anos. Estes casos quando comparados com os dados nacionais e aos do Estado de São Paulo, localizam-se num intervalo de idade mais jovem, já que as maiores incidências para aqueles correspondem à faixa de 25 a 44 anos (SANTOS et al, 2002; BRASIL, 2004a). São semelhantes, entretanto, aos resultados encontrados em outros estudos realizados exclusivamente com gestantes e puérperas (PAIVA, MS., 2000).

Ao longo dos anos, o conceito de família vem sendo ampliado, englobando os casais em convivência estável, tendo inclusive a Constituição Federal do Brasil, 
desde 1988, reconhecido e outorgado direitos à união consensual, por sua predominância entre os casais. Os resultados desse estudo apontam para essa tendência social, já que ela foi encontrada em 5 entrevistadas, mesmo número de mulheres legalmente casadas. As outras 4 atualmente não têm parceiros fixos, morando sozinhas ou na companhia de familiares próximos (pais ou irmãos). Quando questionadas sobre a situação sorológica do parceiro, das 10 que possuem parceiro fixo, cinco deles são soropositivos ao HIV, três negativos e dois não sabem nem a sua situação sorológica, bem como desconhecem que a parceira é portadora do HIV.

A educação básica, dentre as políticas sociais implementadas pelo país, talvez tenha sido a que mais vem experimentando um agravamento na sua situação, principalmente no que se refere à rede pública, o que tem repercutido na diminuição do número de anos de estudo da população de baixa renda. Sabe-se que a escolarização é uma variável importante, pois facilita o acesso ao mercado de trabalho formal e melhores condições salariais.

Em nosso estudo constatamos que uma das entrevistadas não é alfabetizada; 11 cursaram o Ensino Fundamental sendo que apenas 04 o concluíram, e uma concluiu o Ensino Médio. Apenas uma das participantes possui curso superior completo.

Estes dados são corroborados pelos apresentados por Fonseca et al. (2000) e Rodrigues-Júnior e Castilho (2004) que também constataram um aumento de casos de aids nos estratos de menor escolaridade no Brasil, fato este que vem ocorrendo desde o início da década de 90. Para as mulheres, houve uma evolução temporal mostrando um aumento significativo no ritmo de crescimento entre as de menor escolaridade. O nível educacional expressa diferenças entre as pessoas em 
termos de acesso à informação e perspectivas e possibilidades de se beneficiar de novos conhecimentos, e com certeza influencia na apreensão dos conteúdos referentes à prevenção da aids e conseqüentemente, da transmissão vertical.

$\mathrm{Na}$ amostra estudada, a porcentagem de mulheres com ocupação fora do lar foi de $35,7 \%$, sendo que duas entrevistadas relataram que trabalhavam como doméstica, uma como auxiliar de cozinha, uma administradora de empresas e uma profissional do sexo. As demais relataram não trabalhar fora de casa, apenas cuidam dos filhos, dependendo economicamente dos parceiros ou da ajuda de familiares e instituições públicas ou filantrópicas.

A renda familiar informada pelas mulheres variou de zero a 6 salários mínimos. É importante ressaltar que apenas duas entrevistadas relataram renda superior a 3 salários mínimos, sendo que uma delas mora com mais 2 irmãs casadas e empregadas formalmente. A outra é casada, reside apenas com o marido e o filho, e trabalha em função que exige formação superior. Esta última expressa a relação do nível de escolaridade com a situação sócio econômica. Os dados de renda familiar e nível de escolaridade corroboram a tese da pauperização da epidemia.

Alguns autores têm pensado a questão da vulnerabilidade social e a conseqüente pauperização da epidemia da aids em termos econômicos e políticos. É comum que em áreas mais pobres conjuguem inúmeros fatores adversos no que diz respeito à falta de infra-estrutura, baixa oferta de serviços e oportunidades de emprego. Bastos e Szwarcwald, em 2000, apresentaram uma revisão da literatura sobre as inter-relações entre a vulnerabilidade ao HIV/aids e as desigualdades sociais, concluindo que existe a necessidade de novos estudos considerando as especificidades sociais e culturais do Brasil. 
Outro dado que influencia no padrão social da família, é o número de filhos. Em nossa amostra, 4 participantes (28.6\%) tinham 1 filho e 4 tinham 2 filhos. As outras 6 (42.8\%) possuíam mais de 3 filhos, sendo que uma apresentava 13 filhos e estava na $14^{a}$ gestação. Esse dado difere do padrão geral de fecundidade no município, que tem apresentado nos últimos anos um percentual mais alto de mulheres com apenas um filho (em média 45\% nos anos de 2001, 2002 e 2003), com queda nas faixas de maior paridade (RIBEIRÃO PRETO, 2004b).

Com relação à realização do pré-natal, 11 entrevistadas o fizeram no ambulatório do HCFMRP-USP e 1 o fez em consultório particular. Duas mulheres não fizeram o pré-natal, sendo que as duas já sabiam que eram portadoras do HIV. Este dado reforça a necessidade de buscar compreender os motivos que levam algumas mulheres a não realizar todos os procedimentos necessários à prevenção da transmissão vertical, uma vez que elas já tinham conhecimento de sua condição sorológica antes de engravidarem.

Quanto ao padrão de transmissão do HIV, a população estudada retratou os indicadores epidemiológicos configurados atualmente para o país, em que se observa um aumento do número de casos associados à subcategoria de exposição heterossexual, acompanhado de uma proporção cada vez maior de mulheres infectadas, trazendo como conseqüências a diminuição da razão homem/mulher e a possibilidade de aumento da transmissão vertical (RODRIGUES-JUNIOR e CASTILHO, 2004; BRASIL, 2004a). Em nosso estudo, 11 mulheres informaram ter sido infectadas por meio das relações sexuais com seus parceiros e 2 afirmaram não saberem como foram contaminadas. Todas negaram uso de drogas injetáveis. Esse quadro pode traduzir a maior vulnerabilidade feminina em relação à menor capacidade de negociar sexo seguro com seus parceiros. 
Vamos destacar o fato de que uma entrevistada adolescente de 15 anos de idade informa que sua infecção ocorreu por via vertical. Ela faz acompanhamento no ambulatório de moléstias infecciosas em pediatria do HCFMRP-USP há oito anos, e desde então faz uso de medicamentos anti-retrovirais. Comparada com a aids do adulto, a criança geralmente apresenta uma progressão mais rápida da doença. Em relação à sobrevida, esta vem aumentando nos países desenvolvidos devido, principalmente, ao aprimoramento de serviços e de meios diagnósticos e terapêuticos. No Brasil, o trabalho de Chequer et al. (1992) com referência ao período de 1982 a 1989 registrou um tempo mediano de 5 meses de sobrevida; Marins et al. (2003), obtiveram um tempo médio de sobrevida de 18 meses para os pacientes diagnosticados em 1995 e de 58 meses para os de 1996. Matida e Marcopito (2002) mostraram que ao longo do período de 1983 a 1998, houve um aumento constante do tempo de sobrevida das crianças, influenciado principalmente pelo acesso ao diagnóstico, ao acompanhamento clínico-laboratorial e à terapêutica medicamentosa.

Com relação ao conhecimento do "status" sorológico em relação à gestação índice, 8 participantes tinham conhecimento de sua positividade enquanto que 6 só ficaram sabendo durante a realização do pré-natal nesta gravidez. É importante ressaltar também, que das 8 mulheres que já sabiam, 4 delas tomaram conhecimento por meio de exames do pré-natal em gestações anteriores. Os dados corroboram os achados de outros estudos que mostram que o pré-natal ainda é um fator fundamental na identificação das mulheres soropositivas e conseqüentemente para a prevenção da transmissão vertical, uma vez que muitas delas desconhecem seu "status" sorológico antes da gravidez (CAVALCANTI et al, 2004; RUGGIERO, 2000). Isto sugere a necessidade de um oferecimento mais amplo da sorologia à 
população feminina em geral, mediante aconselhamento, antes de engravidar ou planejar a gravidez.

O município de Ribeirão Preto, como já foi descrito, conta com 5 ambulatórios de referência secundária para HIV/aids, além do ambulatório do HCFMRP-USP. Após o parto e puerpério, as mulheres são encaminhadas para acompanhamento clínico em um dos ambulatórios da cidade. Das 14 entrevistadas, 4 relataram que ainda não tinham procurado o atendimento clínico ambulatorial em moléstias infectocontagiosas. As demais já faziam esse acompanhamento, sendo que uma o fazia em consultório particular, através de convênio médico.

Todas as entrevistadas referiram fazer o seguimento clínico especializado da criança, sendo que apenas uma delas o faz em consultório particular. As demais são acompanhadas no ambulatório do HCFMRP-USP.

Com relação à condição sorológica atual da criança, uma apresentou sorologia positiva para o HIV, mesmo a mãe tendo realizado o pré-natal especializado e com uso da terapia anti-retroviral. Todas as outras já apresentam exames negativos em relação à infecção pelo HIV.

\subsection{IDENTIFICANDO AS CRENÇAS}

A partir da transcrição das entrevistas e após a leitura exaustiva das falas, apareceram conteúdos recorrentes e em alguns momentos até contraditórios, refletindo a complexidade que envolve o contexto HIV/aids. Durante o processo analítico emanaram categorias dentro de cada uma das dimensões do referencial 
teórico: susceptibilidade percebida, severidade percebida, benefícios percebidos, e barreiras percebidas.

\section{Quadro 1. Apresentação das dimensões e categorias identificadas}

\begin{tabular}{|l|l|}
\hline \multicolumn{1}{|c|}{ Dimensões } & \multicolumn{1}{c|}{ Categorias } \\
\hline A - Susceptibilidade percebida & 1. invulnerabilidade antes da gravidez; \\
& 2. o pré-natal; \\
& 3.susceptibilidade da criança. \\
\hline B - Severidade percebida & 1. subestimação do HIV; \\
& 2. medo da morte. \\
\hline C - Benefícios percebidos & \\
\hline D - Barreiras percebidas & 1. crescer saudável; \\
& 2. não ser como eu. \\
& \\
\hline & 1. descrença na existência do vírus; \\
& 2. dificuldades financeiras; \\
& 3. omissão do diagnóstico. \\
\hline
\end{tabular}

\section{A - PERCEPÇÃO DE SUSCEPTIBILIDADE}

A susceptibilidade percebida refere-se à percepção subjetiva do indivíduo acerca dos riscos existentes ou de sua vulnerabilidade em apresentar um determinado problema de saúde. Nos casos de agravos já estabelecidos, inclui a 
aceitação do diagnóstico e a avaliação pessoal de sua re-susceptibilidade e da susceptibilidade para doenças em geral (ROSENSTOCK, 1990). A aceitação da susceptibilidade é variável entre os indivíduos que podem negar qualquer possibilidade de contrair uma doença, admitir que existe possibilidade, porém pouca probabilidade de ocorrência ou perceber um risco real de contraí-la (ROSENSTOCK, 1974).

Nesta dimensão identificamos as categorias invulnerabilidade antes da gravidez, o pré-natal e susceptibilidade da criança.

\section{A.1. Invulnerabilidade antes da gravidez}

Quando questionamos as mulheres entrevistadas a respeito do seu conhecimento sobre HIV, praticamente todas referiram conhecer as formas de transmissão, mesmo antes de se infectarem.

"Eu sei que transmite pelo sangue e outras coisas também, tipo relação sexual, machucado, seringa contaminada" (Rosa).

"Pega tendo relação com outra pessoa, ou droga injetável" (Hortência).

"Eu sei que é transmitido por relação sexual, contatos de machucados, pelo sangue. Eu sei também, que não tem perigo de pegar pelo copo, prato, sabe tem gente que tem preconceito e eu descobri que não é nada disso" (Gerânio). 
Tadesse e Muula (2004) e Candundo (2005) referem resultados semelhantes em estudos realizados em Malawi e Angola, na África. No Brasil, Szwarcwald et al. (2004) em seu estudo nacional sobre o conhecimento da população adulta sobre a infecção pelo HIV apontam que 91\% citaram a relação sexual como uma forma de transmissão. Entretanto, ter informações acerca de determinado evento não garante a apreensão e a sua incorporação no comportamento.

Antunes et al. (2002) apontam que aumentar o nível de informação sobre as vias de transmissão do HIV e sobre a necessidade de usar preservativo não garante mudanças comportamentais, o que indica a necessidade dos programas preventivos contemplarem o contexto psicossocial do indivíduo e as diferenças de gênero.

$\mathrm{Na}$ transmissão sexual do HIV, que foi a categoria de exposição predominante, as relações de gênero, ou seja, um comportamento construído socialmente e marcado pela cultura para definir atitudes de homem e mulher, torna ambos mais frágeis e vulneráveis. Enquanto nossa cultura cobra do homem sua virilidade e potência, a mulher tem que ser submissa, criando um contexto social que dificulta a negociação do sexo seguro, tornando-as mais vulneráveis à infecção pelo HIV.

“Eu usei camisinha só durante a gravidez, pra não passar pra ela (referindo-se a criança), depois não usei mais não. Ele não gosta" (Calêndula).

"Eu sabia que devia usar (preservativo), mas me envolvi com uma pessoa lá de São José dos Campos e ele não gostava de usar, e aí aconteceu de eu ficar grávida" (Camomila). 
Para Paiva, V. (2000), é a busca do prazer que direciona para o não compreender a dimensão do perigo existente na relação sexual desprotegida e o conhecimento não é suficiente para promover mudanças comportamentais; as emoções, atitudes e as crenças constituem fatores predisponentes para a adoção de medidas preventivas.

De acordo com Hebling e Guimarães (2004) apesar das mulheres terem informação e conhecerem os riscos, não usam preservativo em relacionamento estável devido à ausência de poder de decisão, pelas relações desiguais de gênero e pelas questões relacionadas à fidelidade conjugal.

O ideal de amor romântico e a confiança no parceiro continua sendo um fator determinante na vulnerabilidade das mulheres à infecção pelo HIV, que ao manterem uma relação estável com vínculo afetivo, não se percebem em risco, conforme observamos nas falas a seguir:

"Transmite por relação sexual, e a gente tinha aquela idéia que como era uma pessoa só que eu tinha, estava tranqüila" (Jasmim).

“Eu não usava porque confiava nele, confiava muito nele e me ralei. Acho até que ele se contaminou por sexo, porque depois eu descobri um monte de coisa dele" (Flor do Campo).

"Não usava porque era casada, gosto muito dele, não podia imaginar isso! Eu culpei meu marido porque ele já sabia e não me contou com medo de me perder; eu até quis largar dele, mas depois a gente foi conversando e passou" (Petúnia). 
A convivência prolongada deixa a mulher com o sentimento de que está imune, e a confiança no companheiro, base das relações amorosas, não leva em consideração a vida pregressa dele. A fidelidade e a situação conjugal aparecem como imunização contra a infecção; a convivência com alguém que se ama e a confiança no parceiro são fatores facilitadores da negação do risco.

Para Araújo et al. (2002) a confiança e a fidelidade são as principais razões para que o casal não use preservativo enquanto método preventivo das infecções sexualmente transmissíveis (IST) e aids. Quando o casal convive há muitos anos cria vínculos de confiança que determinam um comportamento típico de relação monogâmica, que implica na fidelidade da parceria, sem necessidade de prevenção das IST. A prevenção se introduz como uma proposta de mudança no vínculo do casal, alterando o nível de confiança e de contrato. Este fato sendo inserido no imaginário romântico que perpassa o gênero feminino e seus valores, explica o aumento do número de casos do HIV/aids entre mulheres casadas.

Como indica Villela (1999), a desigualdade fomenta a disseminação do HIV e torna necessário um replanejamento das relações de gênero, que também é discutido por Alves et al. (2002).

Apesar de estarmos há 25 anos da descoberta da epidemia, os conceitos de grupo de risco ainda permanecem no imaginário social, contribuindo para que a aids seja vista como a doença do outro, e dando a falsa sensação de distância do perigo.

“Estudar, sempre estudamos, conhecer, sempre conhecemos, tudo. Sabia que era através de relação sexual, que não pode vários parceiros, uso de drogas. Conhecer a gente conhecia, todas as possibilidades de transmitir o vírus, mas jamais esperava que ia acontecer. Quando eu fui fazer o pré-natal foi um susto porque eu 
jamais esperava, até pra ele também, porque ele teve uma outra namorada antes de mim que também era certinha" (Jasmim).

“Eu sabia, mas a gente é assim, quando não é com a gente a gente não sabe nada,acha que nunca vai acontecer com a gente isto, eu mesma nem me preocupava" (Flor do Campo).

A crença inicial de que a aids seria uma doença circunscrita a determinados "grupos de risco" continua sendo um dos empecilhos para a prevenção em mulheres que imaginam que "só os outros podem contrair o HIV". Concordamos com Alves et al (2002) quando apontam que a racionalização falseadora está intimamente relacionada ao fato de que as informações sobre aids foram, durante muito tempo na história da epidemia, transmitidas com a idéia da existência de grupos de risco, que se referiam a tipos-identidades muito estigmatizados (promíscuos, viciados, pervertidos). Ninguém quer se identificar com esses tipos sob risco.

É preciso, portanto, que as ações preventivas contemplem as diferenças de gênero e a desconstrução do conceito de grupos de risco para que as mulheres compreendam e percebam sua susceptibilidade ao HIV/aids.

Um outro fator que consideramos relevante foi o fato da revelação do diagnóstico ter ocorrido durante a gestação, como aconteceu com 6 mulheres, em uma condição na qual não se sentiam vulneráveis:

"O médico pediu todos os exames; depois ele pediu mais uns de novo e deu. Foi a morte pra mim, eu pensei que ia morrer, foi muito difícil" (Flor do campo). 
"Quando a gente ficou sabendo foi aquela coisa, durante uns 2 ou 3 dias a vida parecia que ia mudar. Aí a gente chegou a sentar e conversar que não podia mudar, a gente ia acompanhar, ia ter aquela preocupação só que não ia deixar isso interferir na nossa vida" (Jasmim).

"Eu descobri numa consulta que eu fiz no posto e o médico me deu encaminhamento para o $\mathrm{HC}$ e me perguntou se alguém na minha família tinha o HIV; aí eu levei um susto e perguntei por que ele tava me perguntando aquilo. 'é que seus exames deram que você tem HIV'. Eu fiquei desesperada, caí no choro" (Gerânio).

Diferentemente de quando o indivíduo procura um serviço para realizar o exame anti-HIV, essas mulheres fizeram o teste por ser um procedimento da rotina do pré-natal e não por se sentirem em situação de risco. Se considerarmos que a aids envolve ainda representações negativas ligadas a conflitos, culpa, sofrimento, castigo e morte, a descoberta do diagnóstico nesse momento de realização plena da feminilidade pode ter um alto custo emocional e psicológico, vindo a influenciar as suas decisões posteriores. Se ela tiver uma atitude de negação, ela pode não fazer o pré-natal especializado e nem mesmo o seguimento da criança, enquanto estiver negando a existência do HIV. Essas mulheres necessitam de um suporte emocional e um apoio institucional ainda maiores devido à situação de vivenciarem as fases de aceitação do diagnóstico em um período em que um outro ser está envolvido e em situação de risco. Não só nesse momento, mas especialmente nele, concordamos com Gir et al. (2004) quanto à necessidade de atuação multiprofissional e interdisciplinar no atendimento aos pacientes com a infecção pelo HIV, e que 
considere a abordagem tanto da dimensão psicossocial quanto do contexto sociocultural em que vivem.

\section{A.2. O pré-natal}

Das 14 mulheres entrevistadas, 12 realizaram o pré-natal, entendendo-o como importante tanto para avaliar as condições da mulher como da criança. Este entendimento está presente nas falas:

“É essencial para saber o estado da criança, o acompanhamento e o desenvolvimento, impedir o HIV de passar pra ela" (Lírio).

"Ele previne as crianças, você faz um monte de exames, você não sabe, Deus me livre guarde, você não sabe se a criança vai nascer com defeito, vai nascer não só com HIV mas tem a sífilis e outras doenças" (Hortência).

"Ver se está tudo bem com o nenê, se ele está crescendo bem" (Rosa).

"É uma vida dentro de você que não tem culpa, e o pré-natal é importante para tudo, para saber se o nenê está bem ou está doente" (Orquídea).

Esta percepção se estende à questão da prevenção da transmissão vertical do HIV, no qual a realização do pré-natal em serviço especializado é percebido 
como uma das medidas mais eficientes. Elas percebem que a criança é susceptível e o pré-natal é uma forma de diminuir essa susceptibilidade.

"É muito importante, eles orientam a gente, dá o remédio, a gente toma direitinho, abaixa lá o negócio dos vírus, e a gente fica mais tranqüilo e confiante" (Flor do Campo).

“Pra ele nascer sem o vírus. Fazer o pré-natal ajudou a não passar o vírus" (Violeta).

"É importante porque tem recurso pra tudo, vê como é que está o CD4, se você não faz não sabe. Pensa que está bem e ele pode estar baixo" (Calêndula).

A ausência de detecção precoce da infecção pelo HIV durante o pré-natal representa uma oportunidade perdida de intervenção na gestante infectada, limitando as possibilidades de redução da incidência dos casos de recém-nascidos infectados por transmissão materno infantil. Souza Júnior et al. (2004) concluíram, em seu estudo nacional, que os estrangulamentos do sistema nacional de saúde estão se reproduzindo em todas as etapas do processo, desde a inclusão da gestante para o acompanhamento pré-natal até a ausência de pedido do teste sorológico para HIV e falta de conhecimento do resultado do teste antes do parto. Essa não é a realidade de Ribeirão Preto, onde a rede básica de saúde está estruturada para inserir precocemente as gestantes no atendimento pré-natal, e, mesmo tendo algumas dificuldades relacionadas ao aconselhamento para a realização dos testes nas gestantes, eles estão sendo realizados (NEVES, 2003). As 
gestantes portadoras do HIV após a identificação são encaminhadas para o atendimento especializado no AMIGO. Esta estruturação, entretanto, atende apenas a demanda espontânea, e adota conduta expectante de que a gestante procure o serviço e entenda a necessidade de realizar o pré-natal. As mulheres com menor nível socioeconômico e conseqüentemente com menor acesso às informações, com certa freqüência não têm este entendimento, da mesma forma que não se percebem em risco e nem a sua criança.

“(Quanto ao pré-natal) É importante pra mulher, só que eu não vou atrás não, minha mãe teve um monte de filhos e está todo mundo aí, bem. (Então por quê é importante?) ... é perigoso morrer no parto, é perigoso a água que a criança bebe, é por isso que faz o pré-natal. (E por quê você não faz?) $A h$, eu não. Eu não tenho nada, nunca nem tomei remédio" (Tulipa).

Tulipa é analfabeta, tem 13 filhos, está na $14^{\mathrm{a}}$ gestação e refere nunca ter feito pré-natal, da mesma forma que sua mãe também nunca o realizou. Esse contexto sócio-cultural influencia sua decisão de fazer o acompanhamento de saúde, uma vez que em sua família sempre se reproduziu o comportamento de não procurar médico para atendimento a um evento natural que é a gestação.

Para Souza e Barroso (1997), tomar decisão em saúde é um processo no qual o indivíduo atravessa uma série de estágios em que as interações com pessoas ou eventos em cada um desses estágios o influencia. É preciso estabelecer uma relação de confiança com as pessoas para que estas tenham alguma influência na tomada de decisão. 
Há necessidade de se pensarem ações preventivas em saúde considerando a dimensão sócio-cultural das mulheres. No caso do município estudado, é necessário que se faça uma busca ativa das gestantes que estão fora do atendimento pré-natal, tanto no sentido de facilitar o acesso como tentar a "conscientização" da importância de fazê-lo. A atual estratégia de utilização de agentes comunitários de saúde pode favorecer a interação com essas gestantes. As agentes de saúde são pessoas da própria comunidade, mais próximas da realidade dessas mulheres e por isso têm mais facilidade em interagir com elas. Araújo e Assunção (2004, p.19) referem que o "agente comunitário de saúde - ACS, torna-se o articulador do processo de trabalho da equipe, exatamente por morar na sua área de atuação, conhecer muito bem a comunidade em que vive e ter maior facilidade de acesso aos domicílios". Apontam ainda que o elo acontece principalmente na visita domiciliar, quando o ACS tem a oportunidade de conhecer os problemas das pessoas e comunicar à equipe do Programa de Saúde da Família (PSF) de forma a discutirem ações conjuntas que diminuam ou solucionem os problemas encontrados.

O PSF, atualmente em fase de implantação em algumas regiões da cidade, pode ser uma estratégia para inserir as gestantes que estão excluídas do atendimento pré-natal.

Para as mulheres que fizeram o pré-natal e cujos filhos estão com resultado negativo na sorologia para o HIV, a importância do pré-natal é incontestável, como já vimos nas falas citadas acima. Mas a credibilidade no pré-natal desmoronou naquela mãe em que o resultado não foi favorável para a criança.

“Não sei se é importante, eu fiz tudo direitinho ao pé da letra, mas não resolveu, né, ele é positivo. Eu tomei remédio na hora certa, fui em todas as consultas, fiz todos os exames. Eu não acredito, sabe 
eu me decepcionei muito com o pré-natal, com tudo. Tem mulher que não faz nada na gravidez e o nenê nasce sem o vírus, essa é que era a minha revolta" (Petúnia).

Não há como negar que progressos significativos têm sido obtidos na batalha contra a transmissão materno infantil. Com os avanços na terapia anti-retroviral usada na gestação, alguns estudos clínicos têm mostrado que, aliado às outras medidas profiláticas, as taxas de transmissão vertical estão inferiores a 2\% (EL BEITUNE et al., 2004).

“...então eu procurei saber e fiquei sabendo que era quase impossível ele pegar..." (Petúnia).

No entanto, apesar da taxa ser baixa, o risco ainda permanece. E as mulheres têm que estar cientes desta possibilidade.

Lago e Nunes (2002) em estudo realizado com portadores de fissuras lábiopalatais concluíram que as reações iniciais das mães quando descobrem que seu filho é portador de fissura é de intenso desespero, seguido de sentimentos depressivos como tristeza, frustração, culpabilização e negação; depois a atitude básica é de resignação. Reação semelhante podemos esperar que aconteça com as mães que descobrem que seu filho foi infectado pelo HIV, como observamos a fala de Petúnia abaixo:

"Eu fiquei muito revoltada, morrendo de raiva, decepcionada, parei de conversar com meu marido porque foi ele que trouxe isto pra mim; depois vai passando, eu fui conversando com outras mães que 
estavam lá e graças a Deus eu estou calma, eu tenho que estar, agora ele depende muito de mim" (Petúnia).

A terapia anti-retroviral reduziu inegavelmente as taxas de transmissão materno infantil, porém existe a necessidade de que as mulheres sejam esclarecidas de que o risco, embora reduzido, ainda existe e o seu filho é susceptível a este risco.

\section{A.3. Susceptibilidade da criança.}

Para três mulheres que souberam de sua condição sorológica durante a gestação, o conhecimento prévio de que o HIV pode ser transmitido pela via vertical, ou seja, da mãe para o filho, não fazia parte do seu cotidiano, desconhecendo que o seu bebê era susceptível.

"Antes eu não sabia que passava da mãe para o bebê. Agora eu sei que pode ser através do sangue do cordão umbilical, do parto e durante a amamentação" (Violeta).

"Eu não sabia antes, só fiquei sabendo que o nenê pega depois que eu engravidei e a médica explicou tudo. Antes eu não sabia nada. Fiquei muito preocupada porque eu achava que não tinha remédio para tratar para ele não ter também" (Orquídea).

“Eu não sabia que podia passar pela amamentação, pra mim era só quando tinha relação, mas aí eles me explicaram" (Gerânio).

Da mesma forma como elas não tinham a percepção da própria susceptibilidade, também desconheciam a possibilidade de transmissão da infecção 
para o recém nascido. No ano de 2004, o Programa Conjunto das Nações Unidas sobre HIV/aids (UNAIDS) instituiu, como foco central para a mobilização do Dia Mundial de Luta contra a Aids, as mulheres de todas as idades. Neste sentido foi lançada uma nova campanha em massa de prevenção da transmissão vertical da sífilis e do HIV voltada principalmente para mulheres grávidas, com o objetivo de conscientizá-las da possibilidade de transmissão destas infecções e do direito da mãe e do filho protegerem-se da sífilis e do HIV tendo acesso ao tratamento precocemente.

A percepção de susceptibilidade em relação à criança foi observada nas mulheres que já sabiam que eram portadoras do HIV antes da gravidez:

"Eu achava muito arriscado, graças a Deus o dele já negativou. Eu sabia que podia passar o vírus, mas aconteceu, eu não usava preservativo" (Begônia).

"Teve uma vez que ele tava doidinho pra arrumar filho, mas eu falava imagina, eu não tenho coragem, sabe de parar a pílula por minha conta; se um dia eu tiver que engravidar vai ser tomando remédio. E acabou acontecendo..." (Calêndula).

“Eu tinha tanto medo que fiquei indo os nove meses lá na igreja da catedral e pedindo ai meu Deus, não faz isso com meu filho não" (Hortência).

Elas sabiam da susceptibilidade do bebê e verbalizaram o medo que sentiam em engravidar. Em um estudo fenomenológico sobre a expectativa de pais em 
gestação de risco, Hiluey (1999) relatou o medo que os pais sentiam e como se apegavam ao poder dos médicos e/ou ao divino, para manterem a esperança de verem o bebê saudável. Da mesma forma a mulher soropositiva quando engravida, tem o receio de transmitir o vírus HIV ao filho, presente durante todo o período gestacional. Elas sabem que esta possibilidade é concreta.

Por outro lado estas mulheres também têm recebido a informação de que as medidas preventivas diminuem a chance da transmissão. Esta informação possibilita que a mulher soropositiva manifeste mais abertamente o seu desejo de engravidar.

“Eu sabia que podia passar para o nenê, mas sabia também que tem chance dela não nascer doente. Portanto quando eu fui fazer o pré-natal no postinho eu falei pra mulher lá e ela falou que eu tinha que ir para o HC. Me deram coquetel, eu tomei e até hoje minha filha não tem nada" (Camomila).

"Eu queria engravidar porque falaram que era quase impossível, e eu queria muito ter esse filho, pensei muito, eu tinha um desejo muito grande de ter um nenê..." (Petúnia).

“Por enquanto não, ate estabilizar tudo certinho, se não fosse isso eu teria mais 1, 2 ou 3 filhos. Até sair a cura, quem sabe eu possa ter mais" (Margarida).

"Eu pretendo ter mais filhos, vai demorar ainda mais uns 4 anos. Mas eu quero outro sim" (Orquídea).

O aumento progressivo da infecção pelo HIV entre as mulheres na última década vem trazendo para a discussão a questão dos direitos e as escolhas 
reprodutivas destas mulheres, tema que ainda não é tratado com o cuidado necessário no Brasil. O aconselhamento para o planejamento familiar não é uma ação sistemática ou mesmo prevista na maioria dos programas de aids e os profissionais têm dificuldade em realizá-lo (LANDRONI, 2004).

Para Santos et al. (2002), a infecção pelo HIV não altera a intenção de ter filhos nas mulheres soropositivas, mas os serviços não estão preparados para discutir e ajudar a mulher a fazer esta opção de forma consciente.

Embora as escolhas reprodutivas feitas pelas mulheres possam diferir no mundo inteiro, Barbosa e Knauth (2003) sugerem que os contextos sociais e culturais são mais determinantes que o próprio conhecimento do estado sorológico. Os fatores que afetam as decisões reprodutivas incluem: expectativas de gênero, raça, crenças religiosas, rede de suporte familiar, valor atribuído à maternidade, desejo de ter filhos, disponibilidade da terapia ARV e o apoio do serviço de saúde. Os mesmos autores concluem que no Brasil, o desejo de uma mulher portadoraa do HIV ter filhos pode estar baseado em 2 aspectos: a queda significativa no risco de transmissão materno infantil, proporcionado pelo uso dos ARVs disponíveis gratuitamente a todos os brasileiros portadores do HIV; e o valor atribuído pela cultura brasileira à maternidade, em especial entre os segmentos de menor poder aquisitivo.

Acreditamos que os contextos sociais e culturais são determinantes nas escolhas reprodutivas, bem como sabemos da complexidade das interações existentes entre todos os fatores envolvidos. Os profissionais que lidam com a mulher também estão inseridos neste contexto, sendo influenciados por seus próprios valores e sentimentos. Talvez por isso algumas vezes eles agem de forma a condenar esta mulher por ela ter engravidado, tendo uma postura incriminatória: 
"Desse aí já me criticaram tanto, falaram que foi só porque eu arrumei outro marido. Os médicos falavam, a senhora é louca, a senhora sabe que o nenê pode nascer com o vírus" (Hortência).

“Eu fui no postinho aqui perto e a moça acabou comigo na frente de todo mundo, tava cheio de gente; ela falou que eu não tinha consciência, que onde é que eu tava com a cabeça, que eu sabia do meu problema e mesmo assim eu ia querer ter uma criança defeituosa. Aí eu falei se você puder me ajudar, me ajude, mas se não puder também não taca pedra" (Calêndula).

Neves (2003, p.86) faz a seguinte referência: "devem-se considerar que as crenças, valores e atitudes negativas, assim como a desinformação frente ao HIV/aids, limita consideravelmente a habilidade dos profissionais no atendimento de uma assistência eficaz.". Para Oliveira (2004) a insegurança no trato de questões ligadas à aids e outras IST e sua relação com a gestação é apontada como uma dificuldade encontrada principalmente entre os profissionais das unidades básicas de saúde.

Maksud (2002) refere que o posicionamento dos profissionais de saúde a favor ou contra a gravidez das mulheres soropositivas é, muitas vezes, baseado mais em uma questão de valores do que na competência técnica que lhes é conferida pela sua inserção profissional. Para Reis (2004) os profissionais necessitam reavaliar sua postura ética e profissional em respeito aos direitos sexuais e reprodutivos dos indivíduos soropositivos.

Oliveira e França Jr. (2003) apontam que, para o reconhecimento da autonomia quanto às decisões reprodutivas das pessoas vivendo com HIV/aids, é 
necessária a formulação de estratégias assistenciais que respeitem os direitos humanos e que minimizem os riscos de infecção pelo HIV.

Aconselhamento, apoio para planejamento familiar e uma compreensão ampla da complexidade envolvida nas escolhas reprodutivas por parte dos serviços e profissionais de saúde devem ser aprimorados e estarem presentes nos processos de capacitação, para que as mulheres possam tomar suas próprias decisões conscientes da susceptibilidade da criança, e da possibilidade de transmissão da infecção.

\section{B - PERCEPÇÃO DE SEVERIDADE}

A percepção da severidade está relacionada ao estímulo emocional criado pelo pensamento acerca de um problema de saúde e às conseqüências que o indivíduo acredita que este poderia provocar em sua vida. Sentimentos relativos à severidade de se contrair uma doença ou deixá-la sem tratamento levariam o indivíduo a avaliar as conseqüências clínicas e físicas resultantes, como dor, redução das funções físicas e mentais, temporária ou permanentemente, possíveis conseqüências sociais, como implicações no trabalho, vida familiar e/ou relações sociais, ou até mesmo a morte (ROSENSTOCK, 1990).

Com relação à severidade da doença, duas categorias até certo ponto contraditórias, emanaram das falas das entrevistadas: subestimação do HIV e medo da morte. 


\section{B.1. Subestimação do HIV.}

$\mathrm{Na}$ história da aids existem dois períodos bem delimitados: antes da década de 90, quando prevalecia a imagem da aids ligada à desesperança e morte; e após, com o uso dos medicamentos anti-retrovirais. O advento dessa terapia, em 1996, trouxe a perspectiva de que a aids passaria a ser uma enfermidade crônica, compatível com uma sobrevivência, até então inusitada e, sobretudo, com grande preservação da qualidade de vida. Esta perspectiva se confirmou em estudos que mostram que a sobrevida do paciente com aids aumentou significativamente após esse período, concomitante com a queda nas taxas de internação e mortalidade por aids no Brasil (MARINS et al, 2003; MATIDA e MARCOPITO, 2002).

Essa percepção é sentida pelas mulheres portadoras do HIV e que ainda não manifestaram sintomas, relegando a existência do vírus para segundo plano.

"Como eu só tenho o vírus, não tem muito problema, só se machucar e contaminar outra pessoa ..." (Gerânio).

"Você toma, abaixa a carga viral e continua vivendo normal, é crônico. Igual é como se fosse a minha sinusite, vem aquela dor de cabeça louca, eu corro, faço o tratamento, corrige e então eu quero esperar assim, que é uma coisa que não vai me matar" (Jasmim).

“Fui fazer o pré-natal, o médico me falou e me mandou para o HC. Eu fiquei muito triste né, mas a vida continua, eu não vou morrer de hoje para amanhã se eu me cuidar. Eu não entrei muito em desespero não" (Orquídea). 
"Há 10 anos atrás não tinha recurso; hoje em dia tem o coquetel né. Eu não estou tomando agora, mas eu acho que depois que você que precisa tomar é uma doença que você tem que fazer o tratamento o tempo que tiver que viver" (Violeta).

Elas sabem que têm o vírus, mas relutam em entrar em contato com esta realidade que além de ser dolorosa, impõe um novo direcionamento em suas vidas.Transparece assim, a complexidade contextual da aids, cheia de contradições e incoerências dos sentimentos do ser humano.

Pelo fato da aids ainda ser uma doença associada à morte, uma forma de sobreviver com o diagnóstico de ser portadora é relegar o HIV para segundo plano, não deixando que ele ocupe um espaço grande em suas vidas.

“Ela falou que eu só tenho HIV e que não é pra eu pensar nisso não. A gente fica mais aliviado" (Flor do campo).

"O HIV é assim, tipo câncer, só que o câncer normalmente a pessoa tem tendência, não pega de outra pessoa. Eu prefiro não ficar tão preocupada, se não entro em depressão. Então eu prefiro não preocupar muito não, porque já tá aqui na minha cabeça, entendeu. Eu tenho que levar a minha vida" (Margarida).

Para Knauth (1998, p.145, grifo da autora),

Em primeiro lugar, a depressão é imediatamente relacionada ao pensar em excesso sobre uma situação, no caso a doença. Em segundo lugar, o pensar está intimamente relacionado ao corpo, produzindo efeitos neste.(...) Assim, este ato de pensar sobre a 
doença é identificado como a principal fonte de angústias individuais e é percebido, neste sentido, como um verdadeiro "acelerador" da morte.

Esta percepção é muito clara na fala de Calêndula,

"Se eu colocar na cabeça que eu vou morrer, não adianta vai dar depressão e vou morrer mesmo"(Calêndula).

Concordamos com Ruiz (1999) que conclui que devemos nos esforçar para que a aids não seja tudo, mas apenas uma doença; ela cita Nietzsche "o pensar sobre a doença não deve causar mais sofrimento em si".

O pensar excessivamente em aids é visto como uma forma de rendição à doença, como na fala de Jasmim:

"A gente chegou a sentar e conversar que não podia mudar. A gente ia acompanhar, só que não ia deixar isso interferir na nossa vida. Então é assim, a gente é normal como se não tivesse, quando dá o tempo de fazer os exames, a gente faz, se precisar tomar remédio a gente toma, mas sem nunca abaixarmos a cabeça para isso, nunca deixar que isso seja mais forte que a gente" (Jasmim).

Esta rendição é veementemente recusada, tentando restabelecer a normalidade cotidiana e lutando pela vida.

Revendo novamente a fala de Violeta, 
"Eu não estou tomando agora, mas eu acho que depois que você que precisa tomar é uma doença que você tem que fazer o tratamento o tempo que tiver que viver" (Violeta).

A frase "o tempo que tiver que viver" nos induz a refletir sobre o uso contínuo dos medicamentos que fizeram com que a aids passasse a ser considerada uma doença crônica: como está sendo a vida desses pacientes? Um dos aspectos que emergem é a questão da qualidade de vida a partir da descoberta de que se pode conviver com o HIV, mas em uso contínuo de medicamentos, que trazem o benefício de controlar a doença juntamente com as dificuldades dos efeitos colaterais:

“...eu vi no jornal que o coquetel estava dando até problema de coração, tem outros problemas também que ele pode dar “ (Gerânio).

“...às vezes o remédio mexe com outras coisas, eu tenho isso na minha cabeça, mexe com outras coisas e até prejudica" (Flor do campo).

Além da própria dificuldade em manter o uso contínuo da medicação, os ARV têm inúmeros efeitos adversos que causam uma diminuição na aderência ao tratamento. Em estudo sobre os fatores psicossociais que dificultam a adesão das mulheres portadoras do HIV aos cuidados de saúde, Tunala et al (2000) ressaltam o quão estigmatizante podem ser os efeitos colaterais do coquetel. Com isso, a autoimagem e o estado emocional do paciente são muito afetados, principalmente os do 
sexo feminino, diminuindo a sua auto-estima e o seu bem estar físico e conseqüentemente caindo a qualidade de vida.

O termo qualidade de vida é bastante abrangente, estando diretamente relacionado às experiências individuais, em um dado momento dentro de um contexto sociocultural (MINAYO, HARTZ e BUSS, 2000). Se considerarmos a redução dos índices de mortalidade e internação, Guimarães e Raxach (2002) afirmam que a qualidade de vida dos portadores de HIVlaids melhorou muito. Porém, o uso sistemático dos ARV tem mostrado que eles apresentam efeitos adversos que interferem diretamente no bem estar bio-psico-social e conseqüentemente, na qualidade de vida do paciente.

O alto custo dos medicamentos e os inúmeros efeitos colaterais têm direcionado investigações sobre o impacto dessa terapêutica na qualidade de vida. Canini et al (2004) fizeram uma revisão da literatura sobre qualidade de vida em pacientes portadores de HIV/aids e concluíram que as publicações sobre a temática ainda são escassas no Brasil.

Verificar a qualidade de vida é importante para direcionar as estratégias de tratamento, de distribuição de recursos e os programas de saúde, os quais, por sua vez, podem privilegiar não só os aspectos físicos da clientela, mas também aqueles relacionados às dimensões psíquicas e sociais, possibilitando à equipe de saúde planejar o cuidado integral (CANINI et al., 2004).

Se com as medicações surge a questão da qualidade de vida, por outro lado, sem um acompanhamento especializado no que diz respeito à infecção pelo HIV, as mulheres podem estar se colocando em um risco ainda maior. A adesão ao tratamento e à vida é fundamental para o alcance de melhores resultados. Para que isso seja alcançado a cliente tem que estar ciente da severidade da doença. Entre 
as nossas entrevistadas, 4 mulheres ainda não tinham iniciado o tratamento após o parto.

"Ah, eu não vou em médico não, não tenho nada, nunca nem tomei remédio, e eu nunca vi ninguém com aids" (Tulipa).

A inexistência de sintomas concretos tais como dor, febre e outras alterações perceptíveis, pode resultar em uma descrença com relação à existência do HIV, estimulando um comportamento inapropriado a saúde e não considerando a severidade da doença. Esta questão será novamente abordada como uma barreira a adesão ao tratamento.

Outro aspecto a ser considerado é a crença de que, se evitarem comportamentos comumente associados a doenças em geral, podem estar protegendo-se de desenvolver a aids.

“... assim nunca manifestou coisa em mim, uma que eu me cuido, não bebo, não fico no sereno, não uso droga, essas coisas assim, do meu jeito, mas está indo" (Camomila).

O imaginário de "estar se cuidando", deixando de adotar alguns comportamentos danosos à saúde foi considerado suficiente e apresentado como argumento para evitar a busca pelo tratamento adequado. Porém, essa mesma entrevistada não deixa de levar sua filha ao ambulatório, para evitar que ela se contamine. O papel de "cuidadora" que as mulheres desempenham na sociedade faz com que, para a maioria delas, a primeira responsabilidade seja com a saúde de seus filhos e até com outras pessoas da família e, por isso, muitas vezes não se 
percebem sob risco. Ela negligencia os cuidados adequados com a própria saúde, porém faz tudo para cuidar da filha e evitar que venha a se infectar.

Os profissionais têm que estar sempre preparados em manter uma "escuta ativa" frente às mulheres soropositivas para identificar se o fato de subestimar o HIV é uma atitude positiva, como uma forma de sobrevivência de alguém que conhece a severidade da doença, ou negativa, devido à descrença naquilo que não é concreto e, portanto, não deve ser severo.

\section{B.2. Medo da morte.}

Concomitantemente ao fato de subestimar o HIV considerando-o como um mal menor e novamente realçando a complexidade da aids e suas contradições, o medo da morte e a depressão, que algumas tentam fugir, podem aparecer a estas mulheres até como uma reação normal, na medida em que manifestam os sentimentos de "perda" decorrentes da doença:

"Eu vi gente muito mal no hospital, se não se cuidar, acabou" (Lírio).

"Acho que se a criança nasce com o vírus ela tem pouca possibilidade de viver" (Violeta).

"Eu sei que a aids mata, que HIV mata e dá muita doença, e que se você não se proteger, se você sair com homem vai passar aids para os outros. Se você por na cabeça, vai morrer mais rápido" (Hortência). 
A fala de Hortência revela que a presença do HIV trouxe a certeza da morte, a ansiedade e o medo de morrer, medo esse que é mais acentuado quando se pensa na possibilidade da criança ficar infectada e doente.

Apesar da evolução no tratamento da aids, que aumentou a sobrevida do paciente, nas representações populares a associação entre aids e morte é muito presente. Para Knauth (1998), a associação que as mulheres infectadas fazem com a morte se manifesta principalmente na revelação do diagnóstico. Posteriormente, quando elas vão entrando em contato com os profissionais de saúde e outras pessoas na mesma situação, associado a ausência de sintomas da doença, elas consideram que a morte não é tão imediata como pensavam. Dessa forma, "a invisibilidade da doença permite também a invisibilidade da própria morte". (KNAUTH, 1998, p. 148).

A percepção de morte também se manifesta de maneira desigual nos diferentes grupos sociais. A ameaça concreta de morte é muito mais presente nas camadas sociais mais desfavorecidas da população, que convivem expostas às situações de violência quotidiana e a condições precárias de vida. Para a maioria das mulheres participantes de nosso estudo, que está inserida nestas camadas, a presença da morte independe da doença. A aids é apenas mais uma ameaça, um risco que vem se juntar aos demais.

"...eu penso assim, um dia todo mundo vai morrer, você sai na rua um carro te atropela, leva uma bala perdida, a vida é assim, está nas mãos de Deus, eu penso assim" (Calêndula).

"Eu estou me virando aqui, faz 15 dias que eu voltei para as ruas pra poder pagar a babá e dar as frutinhas pra ela (recém nascido). É 
muito puxado, tem dia que não faz quase nada, os homens tem medo de vir aqui porque o lugar está perigoso, o pessoal está roubando muito; eu tenho que ficar porque está valendo a pena, minha filha está linda!" (Camomila).

A realidade das mulheres que vivem em situações menos favorecidas é de luta constante pela sobrevivência, muitas vezes mobilizando sentimentos de apego a uma crença religiosa. Esse apego também pode se transformar em uma alternativa de enfrentamento da doença:

"Eu entreguei nas mãos de Deus, ele é que vai me dar essa resposta" (Camomila).

“...a saúde dele que está em jogo, mesmo que eu sabia que ele era negativo, mas a gente tem que fazer a parte da gente, que nem Jesus fala, faz a sua parte que eu te ajudarei" (Calêndula).

A religião surge como apoio, representando uma importante rede de suporte emocional. A fé no divino, segundo Santos, Rosenburg e Buralli (2004), é uma forma de explicar o mundo, de superar e suportar o cotidiano da existência, associando-o à esperança.

Em estudo de Teixeira e Lefréve (2003) sobre a fé e o idoso com câncer, os autores assinalam que a fé ajuda o paciente a encarar a própria doença e que os idosos com fé são mais reconciliados com a vida.

A fé na cura se assenta na crença de um poder superior, que lhes dá esperança, conforme observamos nas falas: 
“...quem sabe mais pra frente né, Deus prepara um remédio pra curar" (Flor do campo).

"Eu fiquei 9 meses indo naquela igreja da catedral e pedia "ai meu Deus, não faz isso com meu filho não'; a gente não pode perder a esperança né, tem que levar o menininho e acreditar em Deus" (Hortência).

Na definição de Gertz (1989, p.104-105):

A religião é um sistema de símbolos que atua para estabelecer poderosas, penetrantes e duradouras disposições e motivações nos homens, através das formulações e de conceitos de ordem de existência geral, e vestindo estas concepções com tal aura de fatalidade que as disposições e motivações parecem singularmente realistas.

Muitos estudos abordam as diferentes estratégias pelas quais as religiões reinterpretam a experiência da doença e modificam a maneira pela qual o doente e o meio social definem o problema. Saldanha (2003, p.130), mostrou que "as mulheres se beneficiam de sua crença religiosa, visto que esta se torna fonte de esperança, uma forma de enfrentamento e alívio para o sofrimento, medo e angústia".

Neste caso, a percepção de severidade é tão presente que a crença religiosa é uma forma de suportar as angústias impostas pela doença. 


\section{C - BENEFÍCIOS PERCEBIDOS}

A percepção da susceptibilidade e da severidade da doença pode motivar o indivíduo a tomar uma determinada conduta, porém não define o curso da ação a ser realizada. O que direciona a ação são as crenças pessoais relativas à eficácia das alternativas conhecidas e disponíveis para diminuir a ameaça da doença ou a percepção dos benefícios de se tomar a ação, e não os fatos objetivos que mostram a eficácia da ação (ROSENSTOCK, 1990).

Entre os benefícios percebidos identificamos as categorias crescer saudável e não ser como eu.

\section{C.1. Crescer saudável}

Todas as mulheres participantes de nossa pesquisa estão fazendo o seguimento da criança em ambulatório especializado, sendo que uma faz em consultório médico particular e as demais no AMIB (HCFMRP). Quando questionadas sobre os benefícios que a criança teria em fazer esse seguimento, elas relataram de várias maneiras que o maior benefício é a chance de não ser infectada pelo HIV e ter uma vida saudável.

“Eu queria que ele não pegasse, eu não poderia comprometer a vida dele passando o vírus pra ele" (Violeta).

"Pra ela não ter nada, eu já tinha feito tudo direitinho no pré-natal, aí levei também" (Flor do campo). 
"Pra ele crescer uma criança saudável, não ter nada! (...) Eu acho que ela vai crescer, vai brincar, vai fazer tudo que ela quer entendeu. Enquanto eu tiver aqui trabalhando, eu quero dar tudo que ela quiser, tudo que pode e pronto" (Margarida).

A possibilidade de crescer, brincar e ter uma vida saudável estimula as mães a realizarem as orientações dos profissionais de saúde para diminuir a chance da infecção na criança.

O seguimento ao recém nascido é uma estratégia recomendada a todas as crianças de risco, não só aos que foram expostos à transmissão vertical do HIV. Mello et al (2000) referem que o seguimento é um programa de acompanhamento realizado por um pediatra especialista, que tem como um dos objetivos a detecção e intervenção terapêutica ou profilática.

O acompanhamento em ambulatório especializado é preconizado pelo Ministério da Saúde como uma medida importante para o recém nascido exposto à transmissão vertical, uma vez que determina as ações a serem tomadas durante esse período. Um acompanhamento sistemático dessas crianças deve ocorrer mesmo após a confirmação da sorologia negativa, uma vez que elas foram expostas a agentes com potenciais carcinogênicos (EL BEITUNE et al., 2004).

As mães vêem como benefício da adesão aos procedimentos profiláticos, a possibilidade do filho ter um desenvolvimento saudável e normal, sendo essa percepção preponderante na adesão ao tratamento. 


\section{C.2. Não ser como eu}

As dificuldades vivenciadas pelas mulheres que já sabiam que eram soropositivas antes da gravidez, refletiram no aparecimento de outra categoria, além do crescer saudável: não ser como eu.

"A possibilidade dele não vir a desenvolver a doença, para não ter o HIV" (Lírio).

"Pelo menos eu sabia que ela não ia ser igual eu, ter que ir no médico, ter que tomar remédio, foi um alívio" (Rosa).

“Eu rezava tanto pra Deus pra negativar porque ia pesar pra nós de saber que ele pegou da gente, é uma criança que não tem noção" (Hortência).

Saber que é portador de uma doença crônica, e que você terá que fazer acompanhamento médico, tomar medicações e ter algumas restrições para o resto de sua vida não é uma situação tranqüila.

Entende-se por doença crônica qualquer estado patológico que apresente uma ou mais características, isto é, que seja permanente, que deixe incapacidade residual, que produza alterações patológicas não reversíveis, que requeira reabilitação ou que necessite longos períodos de observação, controle e cuidados. (SMETZER e BARE, 1998).

Conforme relatam Reis e Gir (2001), no período anterior ao advento da terapia anti-retroviral os portadores de HIV/aids necessitavam de longos períodos de 
internação hospitalar mas, atualmente, dispõem da possibilidade de continuarem seu tratamento em níveis ambulatoriais. Entretanto, convivem com as freqüentes consultas médicas, os tratamentos medicamentosos, a rotina ambulatorial e eventualmente, com as doenças oportunistas. Existe a necessidade de adaptação da vida domiciliar a esta nova rotina.

As mulheres que já têm essa rotina em suas vidas, não querem que os filhos também venham a ter. No caso da aids, isso é reforçado pelo fato de ainda ser uma doença com característica estigmatizante para a sociedade. Segundo Guimarães e Ferraz (2002, p.79, grifo do autor),

O estigma é uma construção social, eminentemente de natureza relacional, legitimada pelo olhar do outro. Por outro, entende-se uma rede de normas, códigos e comportamentos de um grupo/sociedade hegemônica, que circunscreve, de forma simbólica ou concreta, territórios de normalidade.

Para os mesmos autores, se algumas pessoas, sob certas circunstâncias, ultrapassarem a linha divisória que separam estas normas, instala-se um desvio que é acompanhado de acusação, isolamento, rejeição e até mesmo punição.

Goffman (1988) considera o estigma como uma forma poderosa que muda radicalmente o modo como os indivíduos vêem a si mesmos e como são vistos por outros indivíduos.

No caso dos portadores de HIVlaids, temos que considerar a forma como a sociedade relacionou-os no início da epidemia: como vítimas, no caso dos infectados por hemoderivados, ou como culpados, no caso dos homossexuais, prostitutas e 
usuários de drogas. Vistos como promíscuos, era atribuída a eles a responsabilidade pela infecção.

Embora ocorreram mudanças ao longo de 25 anos de epidemia, ainda hoje o estigma e o preconceito são receios presentes no cotidiano dos indivíduos infectados.

O benefício de que o tratamento preventivo venha possibilitar a chance de diminuir a transmissão vertical do HIV, impedindo-a de "ser como elas", torna-se um fator importante na adesão ao tratamento.

\section{D - BARREIRAS PERCEBIDAS}

O indivíduo pode acreditar na eficácia de uma determinada ação em reduzir a ameaça da doença e, ao mesmo tempo, perceber esta ação como inconveniente, dispendiosa, perigosa quanto aos efeitos colaterais negativos ou resultados iatrogênicos, desagradável, dolorosa, desconfortável ou que consuma muito tempo. Estes aspectos negativos das ações de saúde ou percepção de barreiras podem agir como impedimentos para a adoção dos comportamentos recomendados e podem gerar conflitos na tomada de decisão (ROSENSTOCK, 1974; ROSENSTOCK, 1990).

Com relação às barreiras ao seguimento, identificamos as categorias descrença na existência do vírus, dificuldades financeiras e omissão do diagnóstico. 


\section{D.1. Descrença na existência do vírus}

Esta categoria, embora tenha sido presença muito marcante em apenas duas participantes, pareceu-nos apresentar aspectos importantes que precisariam ser discutidos, e que podem comprometer o processo de adesão materna, se constituindo em uma barreira. Quando a mulher infectada não consegue reconhecer que o fato de ser portadora do vírus HIV pode trazer graves conseqüências para ela e para os filhos, ela não tem qualquer cuidado para si e nem para a criança. Consideramos que essa "descrença" na existência da doença é uma barreira que a impede de fazer os tratamentos recomendados.

Relatamos abaixo algumas falas de Tulipa:

"Quando o G.nasceu, ele tá com uns 6 anos eu acho, o médico me falou (que era portadora do HIV); depois eu tive as duas meninas, mas eu não acreditava. Eu tô pondo na cabeça que eu tô com isso, então eu vou deixando assim como tá. Eu peço muito a Deus, pra me dar força e cuidar dos filhos. Ninguém acredita que eu tenho, nem eu acredito, então fica por isso mesmo."

“...Eu acho que quem tem aids pode pegar um resfriado forte, uma gripe, não sei. Eu nunca vi ninguém com aids."

"Eu levo ela nas Clínicas porque quando ela nasceu teve um probleminha, bebeu água de parto e ficou um mês internada na UTI da Santa Casa; aí depois me mandaram levar no hospital e eu levo." "Eu nunca levei os outros porque eles não têm nada, nasceram bem, tão tudo forte, nem precisa de médico". 
Estas falas nos remetem a uma situação na qual a descrença vem associada ao analfabetismo e ao contexto de vida em que ela está inserida. Já citamos que Tulipa é analfabeta, com muitos filhos e o atual parceiro (pai de 2 crianças) não sabe que ela é portadora do HIV; ela acha que não precisa falar. Além de nunca ter feito pré-natal, também não levou os outros filhos para seguimento no HCFMRP-USP e, portanto desconhece a situação sorológica deles; acredita que são todos saudáveis. Não usa método anticoncepcional porque o "que Deus quiser ela tem". Mora com o parceiro e os filhos em condições extremamente precárias - 2 cômodos em um barraco de madeira e tijolo. Vive em um contexto em que a luta pela sobrevivência diária está aliada à inércia e à crença de que as coisas são como Deus quer.

Para uma parcela significativa da população, só se toma alguma providência depois do fato instalado, ou seja, depois da manifestação de algum sintoma. Concordamos com Lefrève et. al. (2004), em seu estudo sobre a prevenção da dengue, quando refere que a presença de idéias populares, tais como "as pessoas só acreditarão na doença quando acontecer com elas", sinaliza que parte da população ainda não se sente suficientemente em risco de contrair doença. No caso da situação de já ser portadora do HIV, a presença do vírus não tem um significado concreto, pois ainda não há sintomas aparentes que comprovem a sua existência.

A observação da epidemia de aids tem mostrado que os comportamentos individuais desempenham papel crucial na transmissão do HIV e que as estratégias de prevenção de seu crescimento devem levar esse fator em consideração.

Uma outra forma de descrença ou subestimação do HIV que vamos abordar é a fé religiosa exacerbada que pode se caracterizar como uma barreira ao tratamento. 
Quando o paciente é altamente apegado à sua crença religiosa, como no caso de alguns evangélicos, católicos carismáticos e de outras religiões, a figura do líder espiritual - pastor ou padre - passa a ter uma postura muito ativa dentro de sua vida, podendo até influenciar em seus atos.

Em nosso estudo, uma das participantes possuía esta característica de apego religioso, que permeou todo o conteúdo da entrevista, e nos levou a considerar essa categoria como relevante e influente no que diz respeito à adesão.

Calêndula tem 37 anos, é portadora do vírus há 10 anos, infectou-se através do marido, tem uma filha de 11 anos e um filho de 7 meses, ambos negativos. É evangélica fervorosa e recentemente havia prestado um depoimento na Igreja. Relatamos abaixo alguns trechos de sua entrevista:

“Essa doença vai muito da cabeça e da fé da pessoa, sabe, porque eu não me considero portadora não. Já fiquei com pneumonia uma monte de vez, o remédio não tava combatendo. Aí eu pedi a Deus, eu entreguei nas mãos de Deus; e Deus me libertou."

“Eu não queria engravidar, estava tomando remédio, mas aconteceu. Mas eu não fiquei preocupada porque o Senhor tinha me mandado a palavra. Uma semana antes de perceber que estava grávida, Ele me mandou a palavra dizendo que eu ia ter uma criança forte. Então eu acredito que, graças a Deus, pela minha fé e pela palavra que o Senhor tinha mandado, eu sabia que ele era negativo".

"Quando ele nasceu lá no HC, ele tomou remédio, mas ele teve muita cólica sabe, acho que o remédio mexeu um pouquinho e eu ficava morrendo de dó. Aí eu pensei assim, não vou dar esse remédio não, mas eu não posso falar nada para os médicos... Falei 
que não ia dar mais e não dei. Eu sei que tem que dar o remédio, mas eu acreditei na palavra de Deus, sabia que ele não tinha nada e não dei."

“Eu fiz o pré-natal direitinho, levo ele no HC, mesmo que eu sabia que ele era negativo, mas a gente tem que fazer a parte da gente né, que nem Jesus fala, faz a sua parte que eu te ajudarei".

"Eu tive ajuda em geral de todo mundo; porque o Senhor preparou tudo para ele, porque ele ganhou tudo e ganha até hoje. Na igreja a maior parte sabe que nós somos positivos, mas tem uns que não acreditam não, por isso eu contei sobre a obra de Deus na minha vida".

Para Dantas, Pavarin e Dalgarrondo (1999), a religião promove valores compartilhados, interação e limites sociais fortes que evitam que o indivíduo se sinta isolado e, ao mesmo tempo, estabelecem um conjunto de ideais pelos quais viver. Esta interação e compartilhamento são presentes na vida de Calêndula, no que ela ressalta, do seu ponto de vista, a ajuda que recebeu dos amigos, e tem a coragem de conversar sobre sua vida na igreja.

Figueira (2003) identifica a relação aids e religião como sendo marcada pela harmonia e pelo conflito, em que a doença é ressignificada à luz do discurso religioso. Em Calêndula essa contradição fica evidente quando relata que fez o prénatal e o seguimento da criança porque "Jesus fala, faz a sua parte que eu te ajudarei", ao mesmo tempo em que não dá a medicação para a criança, pois já sabia que ele era negativo. A autora citada, em cuja pesquisa entrevistou pastores e freqüentadores de igrejas evangélicas pentecostais, refere também ao papel que a religião tem exercido nestas situações, tanto no sentido do conforto e proteção ao 
indivíduo quanto à promessa de cura para este, ocupando um espaço de "terapia religiosa".

A descrença no HIV tanto devido ao contexto social de pobreza e baixa escolaridade, como também devido à crença religiosa exacerbada podem se transformar em barreiras para seguir as orientações dos profissionais de saúde e para a adesão às medidas preventivas da transmissão vertical do HIV .

\section{D.2. Dificuldades financeiras}

A maioria das mulheres participantes referiu apresentar dificuldades financeiras para realizar todas as ações preventivas da transmissão vertical, especialmente no que se refere ao comparecimento aos retornos do pré-natal e da criança. Em alguns momentos estas dificuldades podem se constituir em uma barreira.

"A maior dificuldade é o ônibus, tem vez que tem dinheiro e tem vez que não tem. Já até perdi retorno porque não tinha dinheiro" (Lírio).

"Aqui está todo mundo desempregado, o ônibus é difícil e eu não tenho carteira; muitas vezes eu levo ela a pé. Tem dia que chove, tem dia que o sol está quente demais, mas eu vou" (Rosa).

"Eu levo todo mês que é marcado, a única dificuldade é que às vezes não tenho dinheiro pra levar de ônibus, mas eu me viro e vou" (Camomila). 
A vulnerabilidade social em que os indivíduos das camadas sociais mais baixas estão sujeitos fica evidente nas falas acima. Parker e Camargo Jr. (2000, on line, grifo do autor) referem que:

O Brasil, país de dimensões continentais com importantes disparidades sociais, econômicas e demográficas em sua população. É de esperar, portanto, que tais disparidades - e os vários Brasis que elas delimitam - reflitam-se também na forma como o HIV se propaga em nossa população. Dito de outra forma, estas diferentes características conformariam populações diferentes, ainda que em mesmo território, com variações quanto à probabilidade de que seus componentes viessem a infectar-se pelo HIV, configurando, portanto, diferentes vulnerabilidades à infecção pelo HIV e, por conseguinte, à AIDS.

Concordamos com Kerr-Pontes et al. (2004) no sentido de que a pobreza e a falta de perspectiva estão associados à situação de exclusão social e à total ausência de direitos humanos. Estes autores sugerem que a alta vulnerabilidade desses indivíduos relacionada à complexidade sócio-econômica deve ser considerada nos programas de prevenção e controle da aids. Couto (2002) afirma que a inexistência da intersetorialidade na elaboração das políticas públicas brasileiras compromete a resposta integral à dupla vulnerabilidade gerada pela superposição pobreza e aids.

A maioria das participantes relatou a importância da ajuda de instituições públicas e filantrópicas para manutenção dos vários aspectos do tratamento. 
"O leite foi muito importante, porque a gente não tem dinheiro, ônibus é caro, só ele que é aposentado, como é que a gente vai viver, como ia ser com o nenê sem leite? Ninguém dá serviço, você vai se prostituir?" (Hortência).

"A carteira de ônibus que eu consegui me ajudou muito, porque ele tem muito retorno, é na neuro, na TO, não ia dar pra pagar..." (Petúnia).

"Esse leite é caro e a gente não pode dar mamar" (Begônia).

Uma das ações recomendadas para a prevenção da transmissão vertical do HIV é a supressão da amamentação. O aleitamento materno representa risco adicional de transmissão de 7\% a 22\% (BRASIL, 2004b). Nas maternidades do município de Ribeirão Preto, a inibição da lactação é feita através da supressão farmacológica, utilizando-se o medicamento cabergolina.

O risco de transmissão do aleitamento está bem delimitado na fala de uma das entrevistadas, que teve uma filha que se infectou com o HIV através da amamentação:

"Na gravidez da E. (atualmente com 2 anos) eu não fiz pré-natal porque trabalhava, e também dos outros filhos eu não tive nada. Aí ela nasceu prematura. Depois de uns dias, eu já tinha até amamentado, a enfermeira do posto veio me dizer que eu era positiva. Eles fizeram exame nos meninos e viram que a minha filha G. de 5 anos também tinha; só que no pré-natal dela eu tinha feito os exames e foi tudo negativo. Depois me falaram que pega no leite materno e ela mamou no meu peito até eu engravidar da E." (Lírio). 
O aleitamento materno é amplamente difundido nas campanhas publicitárias e nos serviços de saúde como um dos responsáveis pelo crescimento saudável do recém nascido, e sempre associado à proteção, maior vínculo com a mãe e amor materno (JAVORSKI et al., 2004). Para a mulher soropositiva que não pode amamentar, muitas vezes fica a imagem de fracasso na proteção para a criança. 0 seguimento da mãe e da criança deve abordar também este aspecto, com os profissionais de saúde apoiando a mulher na "desconstrução da vontade de amamentar" subsidiando-a com informações de como estabelecer, manter e fortalecer o vínculo afetivo com seu filho, orientando-a quanto ao preparo e administração da fórmula infantil e sobre a introdução gradativa de outros alimentos. A CNDST/AIDS recomenda ainda que os profissionais subsidiem a mulher com argumentos lógicos que lhe possibilite explicar para familiares e outras pessoas de sua comunidade, o fato de não estar amamentando, atendendo assim à sua vontade de manter em sigilo seu estado sorológico de portadora do HIV (BRASIL, 2004b).

Outra recomendação importante é o fornecimento de fórmula láctea para o recém nascido no mínimo até seis meses de vida. Consideramos esta medida fundamental, uma vez que as mães geralmente não conseguem comprar o leite artificial por já se encontrarem em situação econômica desfavorável. O não fornecimento desse leite com certeza comprometeria a nutrição da criança. Em Ribeirão Preto, a Secretaria Municipal da Saúde fornece o leite artificial à criança por 6 meses.

As falas confirmam a necessidade de implementação de políticas públicas, não apenas com ações pontuais, mas com vistas a intersetorialidade abrangendo não só a saúde e a assistência social, mas também a educação, trabalho, cultura e 
lazer para os indivíduos portadores do HIV, como forma de diminuir as barreiras financeiras que comprometem a adesão ao tratamento.

\section{D.3. Omissão do diagnóstico}

Não revelar sua condição de portadora é uma saída diante dos problemas emergentes da situação de soropositividade. Entretanto, concordando com Tunala et al (2000), este silêncio em relação à infecção, além de impedir o seu compartilhamento com outras pessoas que poderiam ajudar no enfrentamento da doença, prejudica a adesão ao tratamento tanto pela dificuldade de ministrar medicamentos na presença dos outros quanto por ter que ficar dando explicações para alguns procedimentos, como por exemplo, a não amamentação. Este silêncio pode se constituir em uma barreira à adesão.

"Ninguém sabe, eles moram aqui do lado e não sabem. Eu disse que a nenê não mamou porque eu ia trabalhar, minha mãe reclamou um pouco, disse que eu tava com preguiça e ela ia ficar doente. Mas eu não contei nada, não sei como ela ia reagir" (Lírio).

A maior parte das mulheres que entrevistamos, principalmente aquelas que se descobriram portadoras durante essa gestação, mantêm sua condição sorológica em sigilo, tendo como único confidente o parceiro ou familiares que residem na mesma moradia.

"Só as minhas 2 irmãs é que sabem; o meu cunhado que mora aqui com a gente não sabe e nem minha mãe, que mora no Sul. Não 
conversei com minha mãe e nem vou contar, ela não ia entender" (Violeta).

"Minha família mora aqui perto, mas ninguém sabe disso, não falei para eles e nem para a minha patroa. Só o meu marido sabe e é quem me ajuda, ele foi uma pessoa muito compreensiva comigo, faz de tudo pra mim" (Margarida).

“O meu pai mora comigo, mas não sabe, nem minha mãe que é separada, ninguém sabe; eu tive medo de contar" (Petúnia).

A preocupação com a revelação de estar infectado, muitas vezes é autoimposta pelo medo que o portador ou doente, tem de, ao tornar conhecido seu diagnóstico, ficar sujeito a preconceitos e estigmatização. Lent e Valle (2000) foram categóricos ao referir que uma grande parte dos indivíduos soropositivos esconde o fato de estarem infectados, pelo maior tempo e da melhor maneira possível, ingressando na clandestinidade quanto à sua condição. Com isso, tenta driblar o isolamento social ao qual poderia estar submetido, inevitavelmente, na maioria das vezes, caso se declarasse portador do HIV.

As autoras, também relatam que as mulheres, para não denunciar a sua doença, utilizam-se de vários subterfúgios: escondem frascos de medicações ARV ou trocam suas embalagens; falam de sua infecção como sendo outra doença; buscam tratamentos em municípios distantes, com medo de serem reconhecidas. Esses recursos foram utilizados por Camomila para realizar o pré-natal: 
"Pra fazer o pré-natal no HC foi uma dificuldade, todo mundo dizia: por que você faz o pré-natal no HC se aqui tem postinho? Lá só vai quem tem aids e sei lá mais o quê. Aí eu falava que tinha sífilis. $E$ até hoje todo mundo acha que eu fui fazer lá por causa da sífilis" (Camomila).

Estas estratégias também servem para proteger os familiares e filhos da discriminação e do estigma que possam sofrer.

Como já afirmamos anteriormente a trajetória da epidemia mostra que ocorreram muitas mudanças, principalmente na forma como ela está sendo vista pela sociedade. No início eram comuns relatos de redução dos direitos de cidadania causados pelo conhecimento público do diagnóstico do HIV, no que Daniel (1994) considerou como "morte civil".

Estes casos foram relatados e veiculados por diversas vezes na imprensa, impregnando o imaginário principalmente daquela camada privilegiada da população que tem acesso à mídia e aos avanços tecnológicos. Para os indivíduos infectados pertencentes a estes estratos sociais a difusão da internet, das salas de bate-papo e das comunidades virtuais, possibilitaram a aproximação com outros indivíduos sem a necessidade da identificação:

"Meu marido entrou muito na internet para pesquisar, para conversar com muita gente que tinha, e muitos já têm o vírus há muito tempo e vivem uma vida normal. Então a gente fica nessa esperança também de ter uma vida normal" (Jasmim). 
Tomamos o exemplo de Jasmim e o marido que têm formação universitária e emprego fixo, e na própria fala dela "já conheciam as formas de transmissão do HIV'. Na sua concepção, estavam distantes dos grupos de risco da aids e da própria tendência atual de pauperização da epidemia plenamente divulgada na imprensa escrita e televisiva; o medo das conseqüências sociais da aids tais como o isolamento social, a discriminação no círculo de amigos e principalmente a perda do emprego, pode fazer com que a omissão do diagnóstico se constitua em uma barreira, diminuindo a adesão ao tratamento.

Dividir com alguém o "peso" do diagnóstico pode trazer conforto e alívio como diz Gerânio:

"Minha família não sabe que eu sou HIV, é só o meu marido e uma vizinha de confiança que eu mesma contei. Ela ficava achando estranho porque eu sempre levava a nenê no médico e eu acabei contando. Ela não sabia muita coisa mas veio me perguntar e hoje está tudo bem. Foi bom ter mais alguém para dividir".

A falta de apoio, o receio do estigma e das conseqüências sociais da aids podem se constituir em barreiras ao tratamento. 
6. Considerações finais 


\section{CONSIDERAÇÕES FINAIS}

A trajetória da epidemia do HIV/aids evidencia claramente a vulnerabilidade da mulher, que apesar de todas as conquistas femininas do último século, ainda permanecem em relações assimétricas de gênero nas questões conjugais, sexuais e sociais. A tendência de feminização da epidemia traz como conseqüência direta a transmissão vertical do HIV, que é a causa de infecção de $90 \%$ das crianças portadoras do vírus.

Os avanços alcançados com a terapia medicamentosa, aliados a outros procedimentos, reduziram consideravelmente a taxa de transmissão materno infantil. Porém, para alcançar estes resultados as mães têm que estar estimuladas a realizarem os procedimentos preconizados pelos profissionais de saúde.

Em nosso estudo, a adesão ao tratamento profilático ocorreu com a maioria das mulheres participantes. Porém, a identificação das percepções acerca da infecção pelo HIV/aids revelou nuances em que pudemos compreender as crenças que influenciam essa adesão.

Para sintetizar, elaboramos um quadro com os achados de acordo com as dimensões do MCS, identificando as crenças e percepções que facilitam ou dificultam a adesão. Alguns aspectos das percepções maternas podem ser considerados tanto como facilitadores como dificultadores da adesão, sendo influenciados pelos fatores modificadores: nível educacional, classe social, personalidade, contexto de vida. 


\section{Quadro 2. Crenças e percepções que influenciam na adesão}

\begin{tabular}{|c|c|c|c|}
\hline Percepções & Crenças & $\begin{array}{l}\text { Aspectos } \\
\text { facilitadores }\end{array}$ & $\begin{array}{l}\text { Aspectos } \\
\text { dificultadores }\end{array}$ \\
\hline \multirow[t]{3}{*}{$\begin{array}{l}\text { Percepção } \\
\text { de risco } \\
\text { (Suscepti- } \\
\text { bilidade) }\end{array}$} & $\begin{array}{l}\text { Invulnerabilidade } \\
\text { antes da gravidez }\end{array}$ & $\begin{array}{l}\text { - informação } \\
\text { - revelação durante o pré- } \\
\text { natal }\end{array}$ & $\begin{array}{l}\text { - relações de gênero } \\
\text {-conceito de grupos de } \\
\text { risco } \\
\text { - revelação durante o pré- } \\
\text { natal }\end{array}$ \\
\hline & Pré-natal & $\begin{array}{l}\text { - percepção da } \\
\text { importância } \\
\text { - acesso } \\
\text { - comportamento } \\
\text { individual }\end{array}$ & $\begin{array}{l}\text { - comportamento } \\
\text { individual } \\
\text { - exclusão do sistema }\end{array}$ \\
\hline & $\begin{array}{l}\text { Susceptibilidade } \\
\text { da criança }\end{array}$ & $\begin{array}{l}\text {-percepção do risco da } \\
\text { criança } \\
\text { - direitos reprodutivos } \\
\text { - aconselhamento familiar }\end{array}$ & $\begin{array}{l}\text { - ausência de informação } \\
\text { - postura dos } \\
\text { profissionais }\end{array}$ \\
\hline
\end{tabular}

\begin{tabular}{llll}
\hline $\begin{array}{l}\text { Percepção } \\
\text { de gravidade } \\
\text { da doença } \\
\text { (Severidade) }\end{array}$ & HIV & - forma de enfrentamento & - uso contínuo de \\
medicação & - qualidade de vida \\
- tratamento & - doença crônica \\
& Medo da morte & $\begin{array}{l}\text { - descrença } \\
\text { - reação inicial } \\
\text { cura) }\end{array}$ & $\begin{array}{l}\text { - morte como uma } \\
\text { constante }\end{array}$ \\
& & $\begin{array}{l}\text { - medo do isolamento } \\
\text { social }\end{array}$
\end{tabular}

\begin{tabular}{lll}
\hline $\begin{array}{l}\text { Benefícios } \\
\text { percebidos }\end{array}$ & Crescer saudável & $\begin{array}{l}\text { - ter vida saudável } \\
\text {-seguimento após } \\
\text { negativação }\end{array}$ \\
& Não ser como eu & $\begin{array}{l}\text { - restrições da doença } \\
\text { crônica } \\
\text { - medo do estigma }\end{array}$ \\
&
\end{tabular}

Barreiras Descrença na

percebidas existência do

vírus

Dificuldades

financeiras

Omissão do

diagnóstico
- analfabetismo

- terapia religiosa

- pobreza/exclusão social -políticas públicas intersetoriais

- esconder as ações preventivas 
É esperado que elas tenham uma racionalidade na busca do cuidado de saúde. Porém essa racionalidade pode ser influenciada por vários fatores, inclusive as suas crenças pessoais e sociais. Elas podem facilitar ou dificultar a adesão às medidas profiláticas da transmissão vertical do HIV. O nível de informação, a história de vida da mulher, seus antecedentes familiares e educacionais, bem como sua situação econômica e cultural interferem na apreensão dos significados e na forma como os aspectos das crenças influenciam seu comportamento, podendo um mesmo aspecto desencadear reações diferentes.

A análise dos dados utilizando os conceitos do MCS destacou alguns pontos que devem ser trabalhados no processo educativo e assistencial das mulheres portadoras de HIV/aids. Devem ser reforçados os aspectos positivos relativos a sua percepção dos benefícios em aderir às medidas profiláticas da transmissão vertical. A determinação da conduta a ser seguida por cada mulher só é possível quando suas crenças e valores individuais são levados em consideração. Identificá-las e compreender como influenciam na condução de um problema de saúde pode determinar a ação dos serviços e a forma como esta ação deve se processar.

Os serviços que atendem os portadores de HIV/aids, em especial as mulheres e as crianças expostas à transmissão vertical, devem estar atentos em implementar programas que extrapolem a dimensão biológica e privilegiem também os valores e a bagagem cultural da clientela, mantendo uma "escuta ativa" e buscando uma assistência mais solidária e participativa. 
7. Referências bibliográficas 


\section{REFERÊNCIAS BIBLIOGRÁFICAS}

ALVES, R.N; KOVACS, M.J, STALL, R et al. Fatores psicossociais e a infecção por HIV em mulheres, Maringá, PR. Rev. Saúde Pública, vol.36, no.4, supl., p.32-39, ago. 2002.

ANTUNES, M.C; PERES, C.A.; PAIVA, V; STALL, R; HEARST, N. Diferenças na prevenção da Aids entre homens e mulheres jovens de escolas públicas em São Paulo. Rev. Saúde Pública, v.36, n.4, p. 88-95, 2002.

ARAÚJO, M.L.M; SANTOS, R; MENDES, A.L; RODRIGUES, L.H; CANELLA, P.R.B. Saber sobre a importância do uso do preservativo influencia o seu uso? Reprodução \& Climatério, v.17, n.1, p. 25-29, 2002.

ARAÚJO, M.R.M; ASSUNÇÃO, R.S. A atuação do agente comunitário de saúde na promoção da saúde e na prevenção de doenças. Revista Brasileira de Enfermagem, Brasília (DF), 57(1): 19-25, jan-fev, 2004.

BARBOSA, R.M e KNAUTH, D.R. Esterilização feminina, AIDS e cultura médica: os casos de São Paulo e Porto Alegre, Brasil. Cadernos de Saúde Pública, vol.19, supl.2, p.365-376, 2003.

BARDIN, L. Análise de Conteúdo. Lisboa, Edições 70 Ltda., 1979.

BASTOS, F.I. e SZWARCWALD, C.L. Aids e pauperização: principais conceitos e evidências empíricas. Cadernos de Saúde Pública, v.16, supl. 1: 53-664, 2000.

BECKER M.H, DRACHMAN R.H, KIRSCHT J.P. A new approach to explaining sickrole behavior in low-income populations. Am J Public Health; 64 (3): 205-16, 1974.

BOWERS, K.A. Explaining health behavior: the Health Belief Model. Nurs Adm Q; 4 (2): p.41-6, 1980.

BRASIL. Ministério da Saúde. Portaria Ministerial número 2104/GM de 19 de novembro de 2002 (on line: www.aids.gov.br. Acesso em 14/11/2004), 2002.

BRASIL. Ministério da Saúde. Coordenação Nacional de DST e Aids. Projeto Nascer. Brasília: MS, 2003a. 
BRASIL. Ministério da Saúde. Coordenação Nacional de DST e Aids. Guia de tratamento: recomendações para a profilaxia da transmissão vertical do HIV e terapia anti-retroviral em gestantes. $2^{\mathrm{a}}$ ed., Brasília: MS, 2003b.

BRASIL. Ministério da Saúde. Aids. Boletim Epidemiológico - Semanas epidemiológicas. Brasília, Ano XVI, n¹, 2004a.

BRASIL. Ministério da Saúde. Coordenação Nacional de DST e Aids. Guia de tratamento clínico da infecção pelo HIV em crianças. Brasília: MS, 2004b.

CANDUNDO, G. Infecções sexualmente transmissíveis e HIVlaids: conhecimento e crença acerca dos riscos entre estudantes do ensino médio de Lubango, Angola - África. 127p. Dissertação (mestrado), Escola de Enfermagem de Ribeirão Preto USP. Ribeirão Preto, 2005.

CANINI, S.R.M.S; REIS, R.B; PEREIRA, L.A; GIR, E; PELÁ, N.T.R. Qualidade de vida de indivíduos com HIVIAIDS: uma revisão de literatura. Rev. Latino-Americana de Enfermagem, vol.12, no.6, Ribeirão Preto, 2004.

CARVALHO, C.V; DUARTE, D.B; MERCHÁN-HAMANN, E; BICUDO, E; LAGUARDIA, J . Determinantes da aderência à terapia anti-retroviral combinada em Brasília, Distrito Federal, Brasil, 1999-2000. Cadernos de Saúde Pública, v.19 n.2, Rio de Janeiro mar./abr. 2003.

CARVALHO, R.L; KRAHE, C; FARINA, G; PAULA, D.O; RICHETTI, N; CROSSETTI, T. Teste rápido para diagnóstico da infecção pelo HIV em parturientes. Rev. Brasileira de Ginecologia e Obstetrícia, v.26, n.4, Rio de Janeiro, p. 325-328, maio 2004.

CAVALCANTI, M.S; RAMOS JÚNIOR, N.A; SILVA, T.M.J; PONTES, L.R.S.K. Transmissão vertical do HIV em Fortaleza: revelando a situação epidemiológica em uma capital do nordeste. Rev. Brasileira de Ginecologia e Obstetrícia, v.26, n.2, Rio de Janeiro, p. 131-138, 2004.

CHEQUER P; HEARST N; HUDES E.S; CASTILHO E; RUTHERFORD G; LOURES $\mathrm{L} ;$ RODRIGUES $\mathrm{L}$ and the Brazilian State AIDS Program Co-Ordinators. Determinants of survival in adult Brazilian AIDS patients, 1982-1989. AIDS; 6(5):4837, may 1992. 
CONNOR, E.M; SPERLING, R.S; GELBER, R et al. Reduction of maternal-infant transmission of human immunodeficiency virus type 1 with zidovudine treatment. $\mathbf{N}$ Engl J Med; 331: 1173-80, 1994. (on line, acesso 10/11/2003).

COUTO, M.H.C. Novos horizontes para as políticas públicas em HIVIAIDS: uma aproximação às questões da contemporaneidade. 2002. 136p. Dissertação (Mestrado). Universidade do Estado do Rio de Janeiro. Rio de Janeiro; 2002.

DANIEL, H. Vida antes da morte. 2 ed. Rio de Janeiro: ABIA, 1994.

DANTAS, C.R; PAVARIN, L.B; DALGALARRONDO, P. Sintomas de conteúdo religioso em pacientes psiquiátricos. Rev. Bras. Psiquiatria, vol.21, no.3, p.158164., jul./set. 1999.

DATASUS. www.datasus.gov.br, on line. Acesso em 24/01/2005.

DELA COLETA, M. F. O Modelo de Crenças em Saúde: uma aplicação a comportamentos de prevenção e controle da doença cardiovascular. 1995. 334p. Tese (Doutorado), Universidade de Brasília, Brasília, 1995.

DELA COLETA, M. F. Modelo de Crenças em Saúde. In: DELA COLETA, M.F. e cols. Modelos para pesquisa e modificação de comportamentos de saúde: teorias, estudos e instrumentos. Taubaté, Cabral Editora e Livraria Universitária, 2004.

DUARTE, G.; GONÇALVES, C.V.; MARCOLIN, A.C.; et al. Teste rápido para detecção da infecção pelo HIV-1 em gestantes. Rev. Brasileira de Ginecologia e Obstetrícia, v.23, nº 02, p.107-111, 2001.

EL BEITUNE, P, DUARTE, G, QUINTANA, S.M. et al. Antiretroviral therapy during pregnancy and early neonatal life: consequences for HIV-exposed, uninfected children. Braz J Infect Dis, vol.8, no.2, p.140-150, abr. 2004.

FIGUEIRA, S. Entre o corpo e a alma: as interrelações do campo sanitário com o campo religioso. 2003.p.161. Tese (Doutorado). Faculdade de Saúde Pública da USP, São Paulo, 2003.

FIGUEIREDO, R.M; SINKOC, V.M; TOMAZIM, C.C et al. Adesão de pacientes com AIDS ao tratamento com antiretrovirais: dificuldades relatadas e proposição de 
medidas atenuantes em um hospital escola. Rev. Latino-Americana de Enfermagem, Ribeirão Preto, vol.9, no.4, p.50-55, 2001.

FONSECA, M.G; BASTOS, F.I; DERRICO, M et al. AIDS e grau de escolaridade no Brasil: evolução temporal de 1986 a 1996. Cadernos de Saúde Pública, vol.16 supl.1, p.77-87, 2000.

GALVÃO, J. AIDS no Brasil: a agenda de construção de uma epidemia. Rio de Janeiro: ABIA; São Paulo: Ed. 34, 2000.

GERTZ, C. A interpretação das culturas. Rio de Janeiro: Zahar, 1989.

GIR, E. A sexualidade e a mulher portadora do vírus da imunodeficiência humana tipo 1 (HIV-1). 1997. 201p.Tese (Livre-docência) - Escola de Enfermagem de Ribeirão Preto USP. Ribeirão Preto, 1997.

GIR, E.; CANINI, S.R.M.S.; PRADO, M.A; CARVALHO, M.J; DUARTE, G.; REIS, R.K. A feminização da aids: conhecimento de mulheres soropositivas sobre a transmissão e prevenção do HIV-1. J Bras Doenças Transm 16 (3): 73-76, 2004.

GOFFMAN, E. Estigma: notas sobre a manipulação da identidade deteriorada. 4 ed. Rio de Janeiro: Guanabara, 1988.

GOLDENBERG M. A arte de pesquisar: como fazer pesquisa qualitativa em ciências sociais. São Paulo (SP): Record; 1999.

GUIMARÃES, M.S; RAXACK, J.C. A questão da adesão: os desafios impostos pela Aids no Brasil e as respostas do governo, de pessoas e da sociedade. Impulso. Rev Ciênc Sociais e Humanas, v.13, p.69-89, 2002.

GUIMARÃES, R.; FERRAZ, A.F. A interface Aids, estigma e identidade - algumas considerações. Revista Mineira de Enfermagem, 6 (1/2): 77-85, jan-dez, 2002.

HEBLING, E.M.; GUIMARÃES, I.R.F. Mulheres e aids: relações de gênero e o uso do preservativo com parceiro estável. Cadernos de Saúde Pública, v. 20 n.5, p.1211-1218, 2004. 
HILUEY, A.A.G.S. Gravidez de Alto Risco: Expectativas dos Pais Durante a Gestação - Uma Análise Fenomenológica. 1999. 229p. Dissertação (Mestrado). Universidade Presbiteriana Mackenzie, São Paulo - SP. 1999.

HOUAISS. Mini-dicionário Houaiss da língua portuguesa. Rio de Janeiro, Editora Objetiva, $1^{\mathrm{a}}$ edição, 2001.

JANS, N.K; BECKER, M.H. The health belief model: a decade later. Health Educ Q ; 11 (1): p.1-47, 1984.

JAVORSKI, M.; CAETANO, L.C.; VASCONCELOS, M.G.L. et al. As representações sociais do aleitamento materno para mães de prematuros em unidade de cuidado canguru. Rev. Latino-Americana de Enfermagem, vol.12, n.6, p.890-898, 2004.

JORDAN, M.S.; LEME, B.; NIGRO, R.; CARACIOLO, J. Aderência ao tratamento antiretroviral em Aids: revisão da literatura médica. In: TEIXEIRA, P.R. et al. Tá difícil de engolir? Experiências de adesão ao tratamento anti-retroviral em São Paulo. São Paulo, Nepaids, 2000.

KASL, S; COBB, S. Health behavior and sick role behavior. Health Education Monographs, v.4, n.2, p. 387-408, 1966.

KATO, C.M. Transmissão vertical do vírus da imunodeficiência humana em dois períodos distintos em um centro de referência em Ribeirão Preto, São Paulo - Brasil. Dissertação (Mestrado); Faculdade de Medicina de Ribeirão Preto USP, Ribeirão Preto 2002.

KERR-PONTES, L.R.S; GONZÁLEZ, F; KENDALL, C; LEÄO, E.M.A; TÁVORA, F.R; CAMINHA, I; CARMO, A.M; FRANÇA, M.M; AGUIAR, M.H. Prevention of HIV infection among migrant population groups in Northeast Brazil. Cadernos de Saúde Pública; 20(1):320-328, jan.-fev. 2004.

KNAUTH, D. Psicoterapia, depressão e morte no contexto da aids. In: ALVES, PC; RABELO, MC. Antropologia em Saúde: traçando identidades e explorando fronteiras. Rio de Janeiro: Editora Fiocruz/ Editora Relume Dumará; p. 139-156, 1998.

LAGO, C.P; NUNES, M.L.T. Reaçöes, sentimentos, atitudes de mäes de portadores de fissuras lábio-palatais e causas atribuídas à malformaçäo. Revista odonto ciênc; 17(37):223-230, jul.-set. 2002. 
LANDRONI, M.A.S. AIDS e gravidez: desafios para o cuidado nos Serviços de Saúde. 2004. 90 p. Dissertação (Mestrado). Faculdade de Saúde Pública. Universidade de São Paulo. São Paulo, 2004.

LEFÈVRE, F; LEFÈVRE, A.M.C; SCANDAR, S.A.S; YASSUMARO, S. Representaçöes sociais sobre relaçöes entre vasos de plantas e o vetor da dengue. Rev Saúde Pública; 38(3): 405-414, jun. 2004.

LENT C, VALLE A. Aids: sujeito e comunidade. São Paulo: IDAC; 2000.

LESCURA, Y; MAMEDE, M.V. Educação em saúde: abordagem para o enfermeiro. São Paulo, Sarvier, 1990.

MAIMAN, I.A, BECKER, M.H. The health Belief Model: origins and correlates in Psycological Theory. Health Education Monographs; 2 (4):336-53, 1974.

MAKSUD, I. Casais com sorologias distintas para o HIV: questões iniciais para debate. In: Associação Brasileira Interdisciplinar em Aids. Conjugalidade e Aids. A questão da sorodiscordância e os serviços de saúde. Rio de Janeiro: ABIA, 2002.

MARINS J.R.P; JAMAL L.F; CHEN S.Y; BARROS M.B; HUDES E.S; BARBOSA JÚNIOR A.E; CHEQUER P.; TEIXEIRA P.R; HEARST N. Dramatic improvement in survival among adult Brazilian AIDS patients. AIDS; 17(11):1675-82, jul 2003.

MARQUES, H.H.S. Infecção pelo HIV na criança. Atualidades em DST/Aids, $2^{a}$ edição. Programa Estadual DST/Aids, Secretaria de Estado da Saúde, São Paulo, 2001, 95 p.

MATIDA, L.H; MARCOPITO, L.F. Aumento do tempo de sobrevida das crianças com aids - Brasil. CNDST/AIDS. Boletim Epidemiológico, ano XV número 02, 2002.

MELLO, D.F; ROCHA, S.M.M.; SCOCHI, C.G.S.; LIMA, R.A.G. O cuidado da enfermagem no seguimento de crianças pré-termo e de baixo peso ao nascer. Rev. Bras. Crescimento e desenvolv. Humano; 10, (1): 49-60, jan-jun, 2000.

MINAYO M.C.S. O desafio do conhecimento: pesquisa qualitativa em saúde. $6^{\mathrm{a}}$ ed. Rio de Janeiro (RJ): HUCITEC; 1999. 
MINAYO M.C.S; HARTZ Z.M.A; BUSS P.M. Qualidade de vida e saúde: um debate necessário. Ciênc Saúde Coletiva; vol.5, n. 1, p.7-18, 2000.

NEVES, F.R.A.L. O aconselhamento para realização da sorologia anti-HIV em gestantes: factibilidades e utopias. Dissertação (Mestrado), Escola de Enfermagem de Ribeirão Preto USP; Ribeirão Preto, 2003.

NISHIMOTO, T.M.I., ELUF NETO, J.; ROZMAN, M.A. Transmissão materno-infantil do vírus da imunodeficiência humana: avaliação de medidas de controle no município de Santos. Revista Assoc Med Bras (1992); 51(1):54-60, jan.-fev. 2005.

OLIVEIRA, L.A; FRANÇA JR., I. Demandas reprodutivas e a assistência às pessoas vivendo com HIVIAIDS: limites e possibilidades no contexto dos serviços de saúde especializados. Cadernos de Saúde Pública, Rio de Janeiro, v. 19, supl. 2, p. 315323, 2003.

OLIVEIRA, R.N. As práticas de saúde para redução da transmissão vertical do HIV em unidades de atenção básica: realidades e determinantes. 126 p. 2004. Dissertação (Mestrado), Escola de Enfermagem USP; São Paulo, 2004.

PAIVA, M.S. Vivenciando a gravidez e experienciando a soropositividade para o HIV. 170 p. 2000. Tese (Doutorado), Escola de Enfermagem USP; São Paulo, 2000.

PAIVA, V. Fazendo arte com camisinha. Sexualidades jovens em tempos de Aids. São Paulo: Summus, 2000.

PARKER, R.; CAMARGO JR., K.R. ;. Pobreza e HIVIAIDS: aspectos antropológicos e sociológicos. Cadernos de Saúde Pública, vol.16, supl.1, p.89-102, 2000.

REIS, R.K; GIR, E. Alterações no estilo de vida, necessidades e dificuldades enfrentadas pelos cuidadores de portadores de aids, no âmbito do domicílio. Rev Esc Enferm USP, 35 (4), 328-335, 2001.

REIS, R.K. Convivendo com a diferença: o impacto da sorodiscordância na vida afetivo-sexual de portadores do HIVIAIDS. 2004. 142p. Dissertação (Mestrado), Escola de Enfermagem de Ribeirão Preto USP; Ribeirão Preto, 2004.

RIBEIRÃO PRETO. Secretaria Municipal da Saúde. Projeto Floresce Uma Vida. Ribeirão Preto, 1995. 
RIBEIRÃO PRETO. Secretaria Municipal da Saúde. Relatório de Gestão 2003. Ribeirão Preto, 2004a.

RIBEIRÃO PRETO. Secretaria Municipal da Saúde. Dados estatísticos. On line: www.ribeiraopreto.saude.sp.gov.br/estatísticas. 2004b (acesso em 10/03/2005).

RODRIGUES-JUNIOR, A.L; CASTILHO, E.A. The AIDS epidemic in Brazil, 19912000: space-time description. Rev. Soc. Bras. Med. Trop, vol.37, no.4, p.312-317, July/Aug. 2004.

ROSENSTOCK, IM. The health belief model and preventive health behavior. Health Education Monographs, San Francisco, v.2, n. 4, p. 354-387, 1974.

ROSENSTOCK, IM. The health belief model: explaining health behavior through expectancies. In: GLANZ, K. Health behavior and health education: theory, research and practice. San Francisco: Jossey-Bass; Chap. 3, p. 39-62. 1990.

RUGGIERO, E.M.S. Gestante portadora do vírus HIV - vida e significado. 174p. Tese (Doutorado), Escola de Enfermagem de Ribeirão Preto USP, Ribeirão Preto, 2000.

RUIZ, J.S. A aids e suas representações. Dissertação (Mestrado), Pontifícia Universidade Católica de São Paulo, São Paulo, 1999.

SALDANHA, A.A.W. Vulnerabilidade e construções de enfrentamento da soropositividade ao HIV por mulheres infectadas em relacionamento estável. 205p. Tese (Doutorado), Faculdade de Filosofia Ciências e Letras de Ribeirão Preto - USP, Ribeirão Preto, 2003.

SANTOS, A.L.D; ROSENBURG, C.P e BURALLI, K.O. Histórias de perdas fetais contadas por mulheres: estudo de análise qualitativa. Rev. Saúde Pública, vol.38, no.2, p.268-276, abr. 2004.

SANTOS, N.J.S.; BUCHALLA, C.M; FILLIPE, E.V;BUUGAMELLI, L. et al. Mulheres HIV positivas, reprodução e sexualidade. Rev. Saúde Pública, vol.36, n.4, supl, p.12-23, ago. 2002.

SMETZER, S.C; BARE, B.G. Doença Crônica. In: BRUNNER, L.S; SUDDARTH, D.S. Tratado de enfermagem médico-cirúrgica. $8^{a}$ ed. Rio de Janeiro: Guanabara. v.1, cap.17, p.275-280. 1998. 
SOUZA JUNIOR, P.R.B.; SZWARCWALD, C.L.; BARBOSA JUNIOR, A. et al. Infecção pelo HIV durante a gestação: estudo-Sentinela Parturiente, Brasil, 2002. Rev. Saúde Pública, vol.38, no.6, p.764-772, dez. 2004.

SOUZA L.J.E.X.; BARROSO M.G.T. Ninguém quer perder um filho: reações dos familiares observadas pela enfermagem. Rev. Brasileira de Enfermagem; 50(4): 477-84, out-dez 1997.

SZWARCWALD, C.L.; BARBOSA JUNIOR, A; PASCOM, A.R.; SOUZA JUNIOR, P.R.B. Pesquisa de conhecimento, atitudes e práticas na população brasileira de 15 a 54 anos, 2004. Boletim Epidemiológico, ano I, n² 1, janeiro a junho 2004.

TADESSE, E; MUULA, A.S. Knowledge and perceptions of antenatal women towards prevention of mother to child transmission of HIVIAIDS in Blantyre, Malawi. Cent Afr J Med. 50(3-4): 29-32. 2004 Mar-Apr. (on line, acesso em 08/02/2005).

TAMBEIRO, N. M. R. Prevenção da transmissão vertical da infecção pelo HIV no Núcleo Integrado da Criança - NIC - Santos, SP 1997 a 1999. 92p. Dissertação (Mestrado), Faculdade de Saúde Pública da USP, São Paulo, 2001.

TEIXEIRA, J.J.V.; LEFÈVRE, F. O capelão e o paciente idoso com câncer: a busca do conforto e da esperança na religião. Mundo Saúde 1995, 27(1):159-164, jan.mar. 2003.

TRIVIÑOS, A.N.S. Introdução à pesquisa em ciências sociais: A pesquisa qualitativa em educação. São Paulo, Editora Atlas, 1987.

TUNALA, L.; PAIVA, V. et al. Fatores psicossociais que dificultam a adesão de mulhers portadoras do HIV aos cuidados de saúde. In: TEIXEIRA, P.R. et al. Tá difícil de engolir? Experiências de adesão ao tratamento anti-retroviral em São Paulo. São Paulo, Nepaids, 2000.

VILLELA W. Prevenção do HIVIAids, gênero e sexualidade: um desafio para os serviços de saúde. In: BARBOSA MR, PARKER R, organizadores. Sexualidade pelo avesso: direitos, identidades e poder. Rio de Janeiro: IMS/UERJ; p. 199-213. 1999.

WHO. Antiretroviral drugs for treating pregnant women and prevention HIV infection in infants: guidelines on care, treatment and support for women living with HIVIAIDS in resource-constrained settings. Geneva, 2004.(online acesso em 10/12/2004). 
Anexos 


\section{ANEXO 1}

\section{INSTRUMENTO PARA COLETA DE DADOS}

Data da entrevista Hora início: Hora término:

Data do parto: Local do parto:

\section{PRIMEIRA PARTE - IDENTIFICAÇÃO}

1) Idade da mãe:

3) Está trabalhando atualmente? ( ) não

4) Até que série você estudou?

5) Número de filhos:

6) Tem parceiro fixo:

( ) sim - informe a sorologia do parceiro: ( ) negativo ( ) positivo ( ) não sabe. ( ) não

7) Quando você descobriu que é portadora do HIV?
( ) antes dessa gravidez
( ) durante essa gravidez
) após esse parto

8) Como você soube que era soropositiva?

9)Como você acha que se contaminou?

10) Você fez pré-natal nessa gestação?

\section{DIMENSÃO DO MODELO DE CRENÇAS}

\section{Percepção de susceptibilidade}

1.1. O que você conhece sobre o vírus HIV?

1.2. Fale sobre a possibilidade de transmitir o HIV da mãe para o bebê.

1.3. Qual a importância do pré-natal para evitar a transmissão do HIV?

1.4. Você pretende ter outros filhos? Por quê? 


\section{Percepção de severidade}

2.1. O que você acha que pode acontecer ao bebê se ele for contaminado pelo HIV?

2.2. Você tem medo que o seu filho possa ficar doente de aids? Por quê?

2.3. Você acredita que com o coquetel a aids ainda é uma doença perigosa? Por quê?

\section{Benefícios percebidos}

3.1. Você leva o bebê para fazer acompanhamento no ambulatório especializado?

3.2. Se você fizer o seguimento adequado, quais os benefícios que o bebê terá?

\section{Dificuldades}

4.1. Você teve alguma dificuldade em comparecer aos retornos?

4.2. Você recebeu auxílio de seus familiares para cuidar do bebê? Eles sabem que você é soropositiva para o HIV?

4.3. Você recebeu algum benefício? (leite em pó, carteira de ônibus, vale transporte, cesta básica, outros).

5. Qual a sorologia do bebê hoje?

6. O que significou para você o resultado dessa sorologia? 


\section{ANEXO 2}

\section{TERMO DE CONSENTIMENTO ESCLARECIDO}

O avanço da epidemia de Aids entre as mulheres tem trazido como conseqüência um aumento significativo do número de crianças infectadas. No entanto, a assistência e o tratamento adequados, instituídos durante o pré-natal, parto e nos primeiros meses de vida do bebê podem prevenir a infecção nas crianças. Neste sentido, estamos iniciando um estudo para conhecer quais são as dificuldades que a mãe HIV positiva encontra para fazer o seguimento do seu filho recém nascido.

Para que possamos responder a esta questão estamos pedindo sua colaboração para que participe de uma entrevista que terá duração de aproximadamente meia hora. $\mathrm{Na}$ entrevista serão feitas perguntas sobre $\mathrm{o}$ acompanhamento do seu bebê e algumas questões sobre sua vida pessoal.

É importante que você saiba que as informações obtidas na entrevista serão confidenciais e não aparecerão, de nenhum modo, em qualquer apresentação pública e nem em nenhum tipo de publicação.

As informações que você der durante a entrevista, em hipótese nenhuma, prejudicarão o atendimento do seu filho ou o fornecimento da assistência à saúde que vocês tem direito a receber, aqui ou em qualquer outro serviço de saúde. Você também pode interromper sua participação na pesquisa no momento que desejar, sem nenhum problema.

Se você tiver dúvidas sobre esta pesquisa ou sobre sua participação, sinta-se à vontade para perguntar agora ou quando necessário.

Meu nome é: Lis Aparecida de Souza Neves.

Meu telefone é: 3977-9332.

Caso você queira participar e está de acordo, por favor, pedimos que consinta assinando este termo.

Data: 104

Assinatura

O responsável pela pesquisa assina o seguinte termo de compromisso com você.

Termo de Compromisso

A pesquisadora, Lis Aparecida de Souza Neves, mestranda da Escola de Enfermagem de Ribeirão Preto da USP, compromete-se a conduzir todas as atividades desta pesquisa de acordo com os termos do presente Termo de Consentimento.

Ribeirão Preto, 104

\section{Lis Aparecida de Souza Neves}

